\title{
Uluslararası Toplumun Kutup Politikaları: Arktik-Antarktika Karşılaştırması
}

Polar Policies of the International Society: The Comparison between ArcticAntarctic

\author{
Aybüke INAN ȘIMȘEK ${ }^{1}$
}

Geliş tarihi: 31.05.2019, Kabul tarihi: 06.09.2019, Basım tarihi: 25.10.2019

\section{$\ddot{\mathrm{O}} \mathrm{z}$}

Küresel iklim değişikliğinin bir sonucu olarak eriyen buzullar, Kutup Bölgeleri'ndeki ekonomik firsatları ortaya çıkarmış ve bu durum iki bölgenin statüsünün sorgulanmasına yol açmıştır. İnsanlığın ortak mirası olarak kabul edilen Antarktika'ya nazaran Arktik, ulus devletlerin egemenlik mücadelesine sahne olmaktadır. Bu çalı̧̧a, İngiliz Okulu teorisinin uluslararası toplum anlayışı çerçevesinde Kutup Bölgeleri’ndeki faaliyetlerini ele almaktadır. Kutup Bölgeleri'nin hukuki, ekonomik ve politik statüsünün karşılaştırıldığı bu çalışmada İngiliz Okulu'nun çoğulcu-dayanışmac1 ayrımı düzen-adalet fark1 kapsamında değerlendirilmiştir. Dayanışmacı uluslararası toplumun adalet anlayışı ile düzen sağladı̆̆ı Antarktika'nın aksine; diplomasi, uluslararası hukuk gibi İngiliz Okulu kuramlarıyla düzen sağlanan Arktik Bölgesi yönetiminde uluslararası toplumun çoğulcu perspektifinin ağır bastığı gözlenmektedir.

Anahtar Kelimeler: Arktik, Antarktika, Ingiliz, Okulu, Uluslararası Toplum, Düzen, Adalet

Jel Kodlar1: K33, Q54, Q58

\begin{abstract}
As a result of the global climate change, the melting ice caps have revealed the economic opportunities in the Polar Regions and this change has led to question the status of the two regions. On the contrary of Antarctic as a common heritage of mankind, Arctic become conflict zone between sovereign nation states. This study analyses the activities of international society in Polar Regions based on the English School theory. Moreover, comparing the legal, economic and political status of the Polar Regions, the distinction between the pluralist-solidarist approaches of the English School was evaluated within the context of the difference between order and justice. Unlike Antarctica, where the solidarity of international community has ensured the order with the perspective of justice; the governance in the Arctic Region provided by the international community is based on a pluralistic perspective, which is regulated by the institutions such as diplomacy and international law of English School theory.
\end{abstract}

Key Words: Arctic, Antarctic, English School, International Society, Order, Justice

Jel Codes: K33, Q54, Q58

1 Akdeniz Üniversitesi, İ̈BF Uluslararası İlişkiler Bölümü, Arş.Gör., aybukeinan@gmail.com

https://orcid.org/0000-0002-4684-380X 


\section{Giriş}

Günümüzde düzen olarak kabul edilen sistem, Batı'da Vestfalya ile ortaya konulmuş bir anlayıştır ve ulus devletleri ortaya çıaran bu sistem, zamanla uluslararası ilişkileri de yönetme ihtiyacı hissetmeye başlamıştır. Bull'a (2002: xxxii) göre dünya düzeni kavramı, uluslararası politik sistemi ve devletler arasındaki ilişkileri ifade etmek için kullanılmaktadır. 20. yüzyllın başlarında ortaya çıkan Uluslararası İlişkiler Disiplini de devletlerarası düzen arayışı sonrasında ortaya çıkan bir bilim dalı olarak değerlendirilmektedir. I. ve II. Dünya Savaşı'nı yaşayan toplumlar tarafindan savaşların nasıl sona ereceği üzerine çalışmalar yapılmış ve bu amaçla pek çok uluslararası ilişkiler teorisi üretilmiştir. İşte bu teoriler içerisinde İngiliz Okulu olarak anılan ve Büyük Britanya'da ortaya çıkan yaklaşım, bu çalışmanın temelini oluşturmaktadır.

$\mathrm{Bu}$ çalışma, dünyanın az bilinen bölgeleri olarak ele alının Kuzey Kutbu'nun ve Güney Kutbu'nun hukuki, politik ve ekonomik statüsünü İngiliz Okulu teorisi nezdinde ele almaktadır. İki Bölge'nin statüsünün karşılaştırılacağı çalısma içerisinde İngiliz Okulu'nun uluslararası toplum düşüncesinden yararlanılacaktır. Ulus devletlerin üstünde onları yönetebilecek bir mekanizmanın olmaması durumu olarak tanımlanan anarşi2 (Bull, 2002: 44) durumunda ulus devletler kendi aralarında düzen kurmaya çalışarak hayatta kalmanın yollarını aramaktadırlar. Çalışmada bu düzen arayışının sonucunda ortaya çıkan uluslararası toplum fikrinin Kutup'lardaki gelişimi aktarılacak ve bu amaçla İngiliz Okulu'nun ele almış olduğu düzen-adalet kavramlarından yararlanılacaktır. Bu makalenin Kutup çalışmaları literatürüne katkı sunması ve gelecek çalışmalara temel oluşturması hedeflenmektedir.

\section{1. İngiliz Okulu Teorisi'nin Gelişimi ve Ele Aldığı Varsayımlar}

II. Dünya Savaşı sonrası dönemde geleneksel Amerikan uluslararası ilişkiler teorilerine alternatif olarak ortaya çıkan İngiliz Okulu (İ) kuramı, 1950'lerdeki Britanya Uluslararas1 Politika Kuram1 Komitesi'nin çalışmalarıyla kurulmuştur (Dunne, 1998: xi). İngiliz Okulu, 1981 yilında bu okulun kapatilmasin talep eden Roy E. Jones (1981: 1-13) tarafindan üretilen bir tabirle adını almıs ve o tarihten itibaren kurum, İngiliz olmayan akademisyenlerin de katkısıyla gelişme göstermiştir. Bir kapatma çağrısı,

\footnotetext{
${ }^{2}$ Hedley Bull'un 'The Anarchical Society: A Study of Order in World Politics" adlı eserinde ele almış olduğu anarși kavramı, toplumları yöneten üst bir hükümetin ya da kuralların yokluğu olarak ifade edilmektedir. Bireylerin aksine egemen devletleri yönetecek ortak bir hükümetin olmaması uluslararası anarşiyi ortaya çıkarmaktadır (Bull, 2002: 44). Bull, uluslararası sistemin anarşik yapısını bu şekilde açılamaktadır.
} 
İngiliz Okulunun uluslararası ilişkilerin temel teorilerinden biri olarak anılmas1 ${ }^{3}$ ile sonuçlanmış ve günümüze kadar gelişimini sürdürmüştür.

İngiliz Okulu, Uluslararası İlişkiler disiplininin gerçekçilik (realism), akılcılık (rationalism) ve devrimcilik (revolutionism) geleneklerinin üçünü de sentezleyerek özgün ve zengin bir çerçeve yaratan temel teorilerinden biridir (Devlen ve Özdamar, 2010: 44). İngiliz Okulu, iktidar ve güç mücadelesini ele alan gerçekçi perspektif ve uluslararası hukukun, kuralların, normların ve kurumların uluslararası ișleyiş biçimlerini ele alan liberal yaklașımın bir karışımıdır (Viotti ve Kauppi, 2012: 239). İngiliz Okulu, gerçekçilik ve devrimcilik yaklaşımlarını dengeleyerek yeni bir orta yol (via media) bulan, gerçekçilik, akılcilık ve devrimcilik düşüncelerini ve uluslararası sistem, uluslararasi toplum ve dünya toplumu gibi analiz seviyelerini sentezleyen eklektik bir teoridir (Hatipoğlu, 2014: 126). Birden fazla dünya görüşünü benimseyip bunları kullanan eklektik yapısı, teorinin en önemli özelliği olarak görülmektedir (Devlen ve Özdamar, 2010: 45).

Uluslararası ilişkiler teorilerinden biri olan İngiliz Okulu'nun ilk dönem yazarlar1 olarak; Herbert Butterfield, Martin Wight, Adam Watson ve Hedley Bull (Avustralyalı) gösterilmektedir (Devlen ve Özdamar, 2010: 45). Robert Jackson, Tim Dunne ve Nicholas Wheeler, İO'nun son yıllarda en fazla öne çıkan isimleridir ve Bary Buzan, Richard Little ve Andrew Hurrell gibi akademisyenlerin katkıları ile İO büyük bir yenilenme yaşamıştır (Linklater, 2013: 123). İngiliz Okulu'nun temel argümanları olarak dört madde ön plana çıkmaktadır. Hedley Bull ve Adam Watson'un çalışmalarından derledikleri bilgilerle bu varsayımları çıkaran Devlen ve Özdamar'a (2010: 48) göre; uluslararası ilişkilerin temel aktörleri egemen devletlerdir; iki veya daha fazla devletin ilişki içinde olup birbirlerine etki edebildikleri bir devletler sistemi bulunmaktadır; ortak bir hükümetin olmamasından dolayı uluslararası sistem anarşik yapılıdır ve bu anarşik yap1 ortak kural, kurum ve normlarla yürütülen uluslararası toplumla düzene sokulmaktadır.

İngiliz Okulu'nu farklı kılan en önemli özelliklerden birisi, dünyanın hem devletlerin hem de devlet dışı aktörlerin faaliyet gösterdiği uluslararası veya anarşik bir toplum olarak anlaşlabileceğidir. (Viotti ve Kauppi, 2012: 239). Temel çalışma konuları olan devletler sistemi, uluslararası toplum, uluslararası toplumda düzen ve düzen-adalet ikilemi üzerine kurumsallaşmaya çalışan İngiliz Okulu (Hatipoğlu, 2014: 127), yeni gerçekçilerin uluslararası sistem, devrimcilerin ise dünya toplumu olarak ele aldıkları analiz düzeyi için "uluslararası toplum" kavramını ortaya atmıştır. $\mathrm{Bu}$ yaklaşım temelde, uluslararası toplumun yapısını, niteliğini ve dağınık devletler sistemi içinde düzen sağlayabilme kapasitesini inceleyerek

\footnotetext{
3 Roy Jones gibi birtakım akademisyenler, İngiliz Okulu'nun ana akım teorilerden biri olamayacağını, İngiliz Okulu olarak ortaya atılan teorinin alternatiflerinin olduğunu belirtmiştir.
} 
uluslararası toplumun farklı bir oluşum olduğunu belirtmektedir (Hatipoğlu, 2014: 128). Herhangi bir yüksek siyasi otorite olmamasına rağmen şiddetin azlı̆̆ının, uluslararası hukuk gibi kurumlar ya da ahlak ve erdem gibi değerlerle büyük oranda sağlanması (Hatipoğlu, 2014: 129); İngiliz Okulu teorisyenlerinin inceleme alanı olmuştur.

'Uluslararası Toplum' kavramı ilk olarak Hugo Grotius'un çalışmalarında kullanılmıştır (Cutler, 1991: 41). Uluslararası toplum, devletler sistemi veya devletlerarası toplum veya devletler toplumu olarak ifade edilen ve devletlerin karşılıklı çıkar ve kimliklerinin kurumsallaşmasıyla ortak norm, kural ve kurumların yaratılmasıyla ortaya çıkan bir kavram olarak karşımıza çıkmaktadır (Buzan, 2015: 12). 1970'lerde Hedley Bull, Martin Wight ve Adam Watson gibi akademisyenlerin İngiliz Okulu'nu kurarak (Linklater, 2013: 123) literatüre kazandırmıs olduğu uluslararası toplum kavramı, diplomatik sistem, diplomatik toplum ve uluslararası hukukun kabulü ile ortaya çıkan kuralların neredeyse tüm bireyler arasında etkileri olan siyasi ve sosyal bir olgu olarak tanımlanmaktadır (Wight, 1992: 30).

İngiliz Okulu, egemen devletlerin anarşik de olsa bir toplum oluşturduğunu ve egemen devletlerden oluşan bu toplumu küresel kurallara uymaya zorlayabilecek daha yüksek bir güce boyun eğmeyeceğini belirtmektedir (Linklater, 2013: 123). Üst bir zorlayıc1 otoritenin yokluğunda şiddetin daha az gerçekleşmesi ise İO'nun dikkat çektiği noktalardandır. Adam Watson'a göre, uluslararası toplumun oluşabilmesi için ortak kültürden gelmenin önemi yoktur'; ortak değerlerin yaratmış olduğu düzenleyici kurallar ve kurumlar, uluslararası toplumun oluşumunda öncül gereçlerdendir (1987: 151).

İngiliz Okulu ilk ortaya çıtı̆ğ dönemlerde uluslararası ilişkiler teorisinin doğası, güç dengesi ve uluslararası anarşik ortamda bir düzen kurabilmenin olanaklarını araştırmıştır (Palabıyık, 2015: 222). Uluslararası anarşide düzenin tesis edilmesi üzerine çalışmalarıyla bilinen Bull (2002: $\mathrm{x}$-xi), düzen ve adalet kavramları üzerine çalışmaları yoğunlaştırmış ve tarihsel yorumsamacı bir metodoloji izlemiştir. Düzen, güç ve güç dengesini ifade ederken aynı zamanda devletlerin ve devlet dışı aktörlerin rasyonel çıarlarına yönelik kuralların ve kurumsal düzenlemelerin kabulünden de geçmektedir (Viotti ve Kauppi, 2012: 240). Düzen, anarşik topluma tercih edilmektedir.

İngiliz Okulu, Immanuel Kant'in ortaya atmış olduğu moral ve etik değerleri kabul etmekle birlikte anarşik toplumda güç ve çıkarın daha önemli olduğu noktalarda pragmatist bir bakış açısıyla bu değerlerin göz ardı

4 Avrupa Devletler Sistemi'nin Hristiyanlık inancı etrafinda oluştuğunu ve bir devletler toplumunun din, dil ve kültür gibi bileşenler etrafında şekillendiğini belirtenler için ise Bull, 1856 Paris Antlaşması ile Türklerin de Avrupa Devletler Sistemi'ne dâhil edildiğini ifade etmektedir (2002: 32). 
edilebilecek olgular olduğunu belirtmektedir (Viotti ve Kauppi, 2012: 240). Hobbes'un realist ve Kant'ın devrimci dünya politikasina orta yol olan Hugo Grotius'un rasyonalizm anlayışını temel alan İngiliz Okulu, uluslararası toplumun rasyonalist bir bakış açısı ile oluşacağını öne sürmektedir (Linklater, 2010: 1). Devletlerin güç ve güvenlik için rekabet etmek zorunda olmadıklarını, anarşi içinde düzeni sağlayabilmek için bir toplum oluşturabileceklerini belirten Linklater (2010: 2), bu toplumun ise ilk olarak Batı'nın kurallarına göre kurulduğunu belirtmiş ve zamanla Batı'ya isyan eden uluslarla, uluslararası toplumun dönüşüm geçirdiğini ifade etmiştir (Linklater, 2013: 142-148).

Batıya isyan uluslararası toplumun genişlemesini sağlamış ve KuzeyGüney ülkeleri ${ }^{5}$ arasındaki ilişkilerin de hız kazanmasına yol açmıştır. 15. yüzyılda Avrupalı toplumların başlatmış olduğu keşifler zamanında dünya üzerinde birkaç bölgesel uluslararası düzen bulunmaktaydı (Bull ve Watson, 1984: 1). Bunları Çin, Avrupa, Hint ve İslam düzeni olarak sıralamak mümkündür (Linklater, 2013: 142). O dönemdeki uluslararas1 düzenin bölgesel kültürlere göre farkllık gösterdiği görülmektedir (Bull ve Watson, 1984: 1). 18. yüzyllın ortalarına kadar Avrupa uluslararası sistemi, Avrupalı olmayan ulus devletleri kendileri ile eşit haklara sahip aktörler olarak değerlendirmemiştir (Bull ve Watson, 1984: 7).

Sömürgecilik çağında Çin ve Japonya gibi toplumların eşit egemenlik mücadelesi Batıya karşı başlatılan isyanların ilki olarak nitelendirilmiş ve adalet arayışı o dönemden günümüze kadar devam etmiştir (Linklater, 2013: 143). 20. yüzyılın başlarında Japonya, Türkiye gibi ülkelerde gerçekleştirilen devrimler bu isyanların sonucu olarak nitelendirilmiş ve daha fazla ülke uluslararası sisteme entegre olmaya çalışmıştır (Linklater, 2013: 144). I. Dünya Savaş'ndan sonra kurulan Milletler Cemiyeti ise Avrupa hâkimiyetinin sonu olarak görülmüş ve uluslararası toplum genişlemeye başlamıştır (Bull ve Watson, 1984: 7). Milletler Cemiyeti'nin kurulmasına kadarki dönemde bölgesel uluslararasi toplumlara sahne olan dünya, bu tarihten itibaren daha küresel düzeyde örgütlenmelere sahne olmuştur. Ancak bu, evrensel bir uluslararası toplum oluştuğu anlamına gelmemelidir (Bull, 1984a: 117).

Ekonomik, askeri ve politik bakımdan karşılıklı ilişkilerin çoğaldığı 20. yüzyllda Avrupalı toplumlar ve Avrupalı olmayan toplumlar arasinda birtakım uluslararası düzenler oluşturulmuştur. Uluslararası toplumun genişlemesine sahne olunan bu dönemde Avrupa, daha önceki sömürgeleri

\footnotetext{
${ }^{5}$ Kuzey-Güney ayrımı, 1980’lerde Brandt Raporları olarak bilinen, dünya üzerindeki ülkelerin yapısal özelliklerinin ele alındığı raporlarla popüler hale gelmiştir. Coğrafi ayrımdan ziyade endüstriyel gelişmenin ayrımına odaklanarak üretilen bu tabir, yapısal eşitsizliğe sahip, refah içerisindeki Kuzey ile yoksul ve bağımlı olan Güney ülkelerini ifade etmektedir. (Heywood, 2013: 191).
} 
ile bile barışçıl, kalıcı ilişkiler kurmaya başlamıştır (Bull, 1984a: 117). Ortak çıkarlar etrafinda birleşen bağımsızlığını yeni kazanmış ulus devletler, güçlü devletlerle işbirlikleri içerisine girerek, uluslararası sistemde söz sahibi olmaya başlamışlardır. Ancak bu dönemde 1919 tarihli Paris Barış Konferansı ile İngiliz ve Fransızlanın Manda Sistemi'ni kurarak sömürgelerine devam etmesi gibi gelişmeler modern anlamda uluslararası toplumun oluşmadığının en büyük göstergelerinden olmuştur (Bull, 1984a: 126). Beyaz 1rkın üstünlüğ̈ fikri tam olarak uluslararası arenadan silinememiştir. Doğu'da yaşanan Bolşevik Devrimi gibi gelişmeler Batı'nın bu sömürgeci anlayışına karşı isyanların da örnekleri arasında gösterilmiştir (Bull, 1984a: 126).

Batıya karşı girişilen başkaldırıları Bull beş kategoriye ayırmıştır: Eşit egemenlik mücadelesi, anti-sömürgeci devrim, 1rk eşitliği mücadelesi, ekonomik adalet mücadelesi ve kültürel mücadele (Bull, 1984b: 220-222). 1945 sonrası dönemde ortaya çıkan Üçüncü Dünya Ülkeleri, uluslararası toplumun kökünden dönüşmeye başladığının ilk sinyallerini vermiştir. II. Dünya Savaşı'nda Batı toplumunun uğratmış olduğu büyük yıkım ile birlikte Üçüncü Dünya ülkelerinin çıkarlarını koruma konusunda daha bilinçli davranması sonucunda Batı'nın hegemonyası zayıflamıştır (Bull, 1984b: 224). II. Dünya Savaşı sonrasında Birleşmiş Milletler Sistemi'nin kurulması ile farklı bir boyut kazanan uluslararası toplum, Soğuk Savaş'ın iki kutuplu uluslararası sisteminde de Batı'nın hegemonyası altında kalmamıştır.

İki kutuplu sistemin ve Soğuk Savaş'in sonra ermesiyle ortaya çıkan uluslararası sistem, uluslararası toplumun da dönüşümüne ve gelişimine yol açmıs, İngiliz Okulu teorisi de bu şartlar altında gelişme göstermiştir. Bull'un ortaya atmış olduğu düzen-adalet kavramlarını çalışmalarında ele alarak çoğulcu-dayanışmacı tartışmasını sürdüren ikinci nesil İngiliz Okulu akademisyenleri, İngiliz Okulunun tekrar canlanmasını sağlamıştır (Devlen ve Özdamar, 2010: 54). "Dayamısmacı-çoğulcu tartısmasımın özü uluslararası toplumun doğası ve potansiyeli üzerinedir." diyen Devlen ve Özdamar'a (2010: 55) göre, çoğulcular devlet merkezli pozitif hukuk anlayışıyla hareket ederken, dayanışmacılar insan merkezli doğal hukuk anlayışını benimsemektedirler.

Egemenlik, diplomasi ve müdahale etmeme ilkesini benimseyen çoğulcuların aksine dayanışmacılar ortak ahlaki normlara ve daha müdahaleci bir uluslararası düzene inanmaktadırlar (Buzan, 2001: 478). Statüko eğilimi gösteren çoğulcular, devletlerarası düzenin sürdürülmesine önem vermektedirler (Buzan, 2015: 16). Çoğulcular düzenin adaletten daha önemli olduğuna inanarak dayanışmacılardan ayrılmaktadır. Dayanışmacılar ise devletler sisteminin, bir arada olma mantığı ile üretilmiş işbirlikleriyle temsil edildiğini belirtirler ve adalet olmadan düzenin kurulamayacağını ifade ederek, adaletin önemine vurgu yaparlar (Buzan, 2015: 16). 
Buzan, dayanışmacı uluslararası toplumun dünya toplumu ile aynı olmadığına dikkat çekmektedir (2001: 478). İngiliz Okulu teorisyenlerinin kendi aralarında çoğulcu-dayanışmacı olarak ayrışmasının yanında Buzan (2015: 86), İngiliz Okulu'nun adalet/sorumluluk kavramları ile güç/çıkar kavramlarının ele alınış biçimleri noktasında uluslararası topluma aracılık ettiğini savunmaktadır. Çoğulcu ve dayanışmacı olarak ayrışan İngiliz Okulu teorisyenlerinin temel amacinın, uluslararası toplumda düzen ve adalet arasındaki dengenin nasıl bulunabileceğiyle ilgili olduğunu belirten Buzan (2015: 16), iki yaklaşımın birbirini tamamladığını iddia etmektedir. Çoğulcu uluslararası toplum devleti merkezine koyarken, dayanışmacı yaklaşım devletin yanında bireyler ve devlet dışı aktörleri de merkezine almaktadır ve işbirliği konusunda çoğulcular sınırlı bir bakış açısı sergilerken, dayanışmacılar geniş çaplı işbirliklerinden bahsetmektedirler (Ronnfeldt, 1999: 144).

İngiliz Okulu'nda dikkat çeken diğer bir unsur da İngiliz Okulu'nun kurumlarıdır. "Bir toplum ya da camiada tesis edilmis gelenek, bukuk veya iliski biçimi” şeklinde yorumlanan kurum kavramı (Buzan, 2015: 16), İngiliz Okulu içerisinde birincil ve ikincil kurumlar olarak iki farklı kategoride ele alınmaktadır. Birincil kurumlar olarak; egemenlik, güç dengesi, ülkesellik, savaş, uluslararası hukuk, diplomasi, insani eşitlik, piyasa, milliyetçilik gibi kavramlar gösterilmekte iken; ikincil kurumlar olarak ise belirli bir amaca hizmet etmek için hükümetlerarası oluşturulan Birleşmiş Milletler, Dünya Ticaret Örgütü, Dünya Bankası gibi yapılanmalar gösterilmektedir (Buzan, 2015: 17). Bull'un çalışmalarında ele almış olduğu güçler dengesi, uluslararası hukuk, diplomasi, savaş ve büyük güçler dengesi gibi kurumlar, Buzan'ın tabiriyle birincil kurumlardır. Bary Buzan, ulus devletlerin ortaya çıkarmış oldukları örgütlenmeleri ikincil kurum kategorisinde ele alarak bu alana bir yenilik getirmiştir. Çoğulcular güçler dengesi, diplomasi, büyük güçler ve savaş gibi klasik kurumları ele alırken, dayanışmacılar bunlara ek olarak insani güvenlik kurumunu da çalısmalarına katmaktadır (Ronnfeldt, 1999: 144).

Bütün bu bilgilerden hareketle bu çalışmanın kapsamı itibariyle İngiliz Okulu'nun uluslararasi toplum kavramından yararlanılmaktadır. Bull'un adalet-düzen konusunda yapmış olduğu ayrıma nazaran Buzan'ın bu iki kavramın uluslararası topluma aracılık ettiği varsayımıla hareket edilecek olan bu çalışmada, uluslararası toplumun Kutup politikaları çoğulcudayanışmacı perspektifle irdelenecektir. Düzen-adalet kavramlarının Kutuplara yansımalarının tartışılacağı çalışma içerisinde İngiliz Okulu'nun ortaya atmış olduğu, güçler dengesi, diplomasi ve uluslararası hukuk gibi birincil kurumlarından yararlanilırken, ikincil kurumlarda ele alınacak; Kuzey Kutbu ve Güney Kutbu'nun karşılaştırılmalı analizi yapılacaktır. Bu amaçla öncelikle Kutup Bölgeleri'nin hukuki, siyasi ve ekonomik statülerinin irdelenmesi yerinde olacaktır. 


\section{Kutup Bölgeleri'nin Hukuki, Siyasi ve Ekonomik Statüsü}

Kutup Noktas1; "Yer Ekseni'nin Yeryürü'nü deldiği benimsenen iki noktadan her biridir" (Sanır, 2000: 184) ve Kutup bölgeleri, Kuzey Kutup Bölgesi ve Güney Kutup Bölgesi olarak ikiye ayrılmaktadır (Sanır, 2000: 184). Kuzey Kutup Bölgesi'ne Arktik, Güney Kutup Bölgesi'ne ise Antarktika denilmektedir. Antarktika etrafı okyanuslarla çevrili donmuş bir kıta olmasına nazaran Arktik etrafı kıtalarla kaplı donmuş bir okyanustur (Attenborough, 2011).

Küresel iklim değişikliğinin bir sonucu olarak bu iki Kutup üzerinde buzullar hızla erimektedir. Ortaya çıkan potansiyel enerji kaynaklarının yanı sıra turizm, tarım ve ulaşım olanakları Kutup Bölgeleri'nin cazibesini arttırmaktadır. $\mathrm{Bu}$ cazibenin yanında iklim değişikliğinin etkisiyle ortaya çıkan buzul erimelerinin yaratmıs olduğu problemler küresel düzeyde önem tașımaktadır. Grönland ve Antarktika'da eriyen buzulların suya karıșması ile deniz seviyesinin yükselmesi ve bunun bir sonucu olarak deniz seviyesine yakın yerleşim alanlarının risk altında olması, tarım alanlarının bu erimeden etkilenecek olması gibi küresel sorunlar tüm dünyayı ilgilendirmekte ve çözüm olanakları küresel düzeyde önem taşımaktadır (Uysal Oğuz ve Ersoy, 2016: 163). Ulus devletlerin oluşan bu dönüşüme tepkileri küresel düzeyde yönetişim tartışmalarını da beraberinde getirmiştir (İnan Şimşek, 2018: 49). Güney Kutup Bölgesi üzerinde var olan mevcut yönetişim modeli, Kuzey Kutup Bölgesi ile birtakım farklılıklar arz etmektedir. İki Kutbun hukuki, siyasi ve ekonomik statüsü birbirinden farklıdır. Uluslararası toplumun bu bölgeler üzerindeki politikalarını ele almadan önce, Güney Kutbu'nun ve Kuzey Kutbu'nun bu statülerini ele almak yerinde olacaktır.

\subsection{Güney Kutup Bölgesi'nin Hukuki, Ekonomik ve Siyasi Statüsü}

Antarktika Antlaşması'nda $60^{\circ}$ güney paralelinin altında kalan alanları ifade eden (Madde 6) dünyanın en soğuk ve kurak kıtası yaklaşık 14 milyon km²'lik Antarktika, Avustralya'dan iki kat, Birleşik Krallık'tan da 57 kat büyüktür (Drewry, 2008: 6). Antarktika'nın sadece \%2,5’i buzsuz iken diğer bölgeleri buz ile kaplıdır (Drewry, 2008: 7). Ortalama 2,300 metre yüksekliğiyle dünyanın en yüksek kıtası olan Antarktika'nın en alçak yeri deniz seviyesinin 2540 metre altında yer alan Bentley Buzulaltı Çukuru, en yüksek yeri ise deniz seviyesinden 4897 metre yükseklikteki Vinson Dağlarıdır (CIA, 2017).

Antarktika Kıtası Dünya'nın bilinen en soğuk bölgesidir ve Arktik Bölgesi'nden birçok konuda ayrılmaktadır. Dünyanın bu soğuk bölgesine deniz yoluyla ulaşım çok zor olmasına karşın, tarih boyunca keşifler düzenlenmiş ve kıta üzerindeki faaliyetlerde de farklılıklar gözlenmiştir. Kıta üzerinde gerçekleşen faaliyetler göz önüne alındığında Antarktika, ticaretin hâkim olduğu dönem, emperyal aktivitelerin yaşandığı dönem, bilimsel 
dönem ve kaynakların önem kazandığ1 dönem olmak üzere dört temel sürece ayrilabilir (Triggs, 2008: 3).

Antarktika üzerinde gerçekleşen faaliyetler göz önüne alındığında ilk olarak ulus devletlerin ekonomik çıkarları göze çarpmaktadır. Kıta üzerindeki uluslararası çıkarlar 18. ve 19. yüzyıllardaki keşiflerle başlamaktadır ve bu dönemde balina avcllı̆ı ve ticareti gibi ekonomik aktiviteler göze çarpmaktadır. Bu ticaret çağını 1890'lardan 1940'lara kadarki dönemde emperyal bir düzen izlemektedir (Triggs, 2008: 3). Kahramanlar çağı olarak da adlandırılan bu dönemde, keşifler yapılmakta ve karasal kolonileşme faaliyetleri hız kazanmaktadır (Triggs, 2008: 3). Kıtanın keşfine yönelik çalışmalar 17. yüzyılda başlasa da Antarktika Kıtası'nın en tepe noktasina ilk ulaşan isim 1911 yllinda Norveçli kâşif Roald Amundsen olmuştur (Atvur, 2017: 95). 1957-58 Uluslararası Jeofizik Yılı (IGY) sonrasında ise Antarktika, bilimsel aktivitelerin düzenlendiği ve barışçıl amaçlı kullanımının söz konusu olduğu bir alan haline getirilmiştir (National Academy of Sciences, 2005). 1959 Antarktika Antlaşması da işte bu bilimsel dönemin eseridir. Gelişen teknolojiye paralel olarak ise, canlı ve cansız doğal kaynakların kıta etrafinda keşfedilmesi ile birlikte, kıta üzerinde ve etrafında kaynak paylaşımı problemleri baş göstermiştir. Kaynak yönetişim sorunları da Antarktika'nın girdiği son dönemi oluşturmaktadır.

Antarktika'nın geçirmiş olduğu bütün bu süreçler, kimseye ait olmayan (res nullius) bu kara parçasının ve etrafinda bulunan deniz alanlarının yönetişim problemlerini doğurmuş ve beraberinde Antarktika Antlaşması'nı getirmiştir. 1 Aralık 1959 yılında 12 ülkenin katılımıyla imzalanan Antarktika Antlaşması 1961 yllında yürürlüğe girmiştir ve Antlaşma’nın bugün itibariyle 54 adet tarafi bulunmaktadır (The Antarctic Treaty Secretariat, 2011). Antlaşmanın maddeleri ise ülkeleri, egemenlik kavramına bakışları noktasında ayırmaktadır. Antarktika üzerindeki egemenlik anlayışında ulus devletler dörde ayrılmaktadır: Antarktika'da karasal egemenlik iddiasında bulunan taraf ülkeler, herhangi bir egemenlik iddiasinda bulunmayan ve mevcut tüm egemenlik iddialarını reddeden taraf ülkeler, mevcut hiçbir iddiayı kabul etmeyip gelecekte oluşabilecek egemenlik iddialarında yerini hazırlayan taraf ülkeler ve kıtanın insanlığın ortak mirası olması gerektiğini belirten taraf ve taraf olmayan ülkeler (Triggs, 2008: 51).

Antlaşma yürürlüğe girdiği zaman toplam yedi ülkenin egemenlik iddiaları söz konusu olmuştur. Bu ülkeler; Birleşik Krallık, Yeni Zelanda, Fransa, Avustralya, Norveç, Şili ve Arjantin olarak sıralanmaktadır. Arjantin, Şili ve Birleşik Krallık'ın toprak iddiaları çakışmaktadır (Triggs, 2008: 51). Arjantin, Şili, Yeni Zelanda ve Avustralya'nın coğrafik yakınlığ sebebiyle egemenlik iddiaları mevcut iken, diğer ülkeler yapmış oldukları keşifler sebebiyle egemenlik iddialarını sürdürmektedir (Triggs, 2008: 51). ABD, SSCB, Belçika, Japonya ve Güney Afrika'nın da Antlaşma’ya taraf devletlere 
eklemlenmesi ile Antlaşma'nın İstişari Devletleri 12'ye çımıştır. Ancak 1959'da imzalanan Antarktika Antlaşması'nın 4. maddesi gereğince egemenlik iddiaları dondurulmuş ve yeni bir egemenlik iddiası da kabul edilmemektedir. Antlaşmaya taraf ülkeler Antlaşma yürürlükte olduğu müddetçe egemenlik iddialarından vazgeçmişlerdir ve Kıta üzerinde gerçekleştirecekleri faaliyetler de onlara herhangi bir egemenlik hakk1 kazandırmayacaktır (The Antarctic Treaty Secretariat, 2011).

Antlaşmanın önsözünde tüm insanlığın çıkarı için kıtanın sonsuza dek barışçıl amaçlarla kullanımının söz konusu olması (The Antarctic Treaty, 1959: 2), Antarktika'nın res communis olduğunu akıllara getirmektedir. Kimseye ait olmayan anlamina gelen res nullius ilkesinin aksine res communis herkese ait olan anlamına gelmektedir (Kiss, 1985: 423) ve Antlaşma'nın önsözünde Kıta'nın barışçıl amaçlarla tüm insanlık yararına kullanımının esas olduğu kabul edilmiştir. Barışçıl amaçlarla kullanımı tüm uluslara aitken, egemenlik bakımından Antarktika'nın kimseye ait olmaması ise res nullius ilkesinin benimsendiğinin delilidir. Res nullius kavramının kullanımı aynı zamanda o bölgede bulunan kaynakların çıkarımının ve kullanımının özgürce yapilması anlamına da gelmektedir (Kiss, 1985: 424). Ancak Antarktika Kıtası, Antlaşma'nın imzalandığı tarihten itibaren res communis ilkesine tabi olmuştur ve beraberindeki antlaşmalarla bu statüsünü korumaktadır.

Antarktika Kitası üzerinde var olan hukuki düzenin ortaya konmas1 amacı ile tarihsel perspektifteki gelişim anlaşılmak zorundadır. Antarktika Antlaşmalar Sistemi (ATS) olarak anılmasında 1959 tarihli Antarktika Antlaşması'nın yanında Kıta için oluşturulan diğer antlaşmaların etkili olduğu görülmektedir. 1959 Antarktika Antlaşması'na ek olarak; 1972 tarihli Antarktika Fokları Sözleşmesi, 1980 tarihli Antarktika Deniz Canlı Kaynaklarını Koruma Sözleşmesi (CCAMLR) ve 1991 tarihli Antarktika Antlaşması Çevre Koruma Protokolü, Kıta üzerindeki hukuki düzenin oluşmasında etkili olan metinlerdir.

1959 tarihinde kabul edilen Antarktika Antlaşması'nda Kıta üzerindeki doğal kaynaklara ilişkin faaliyetleri düzenleyen herhangi bir madde bulunmamaktadır. 1980 tarihli Antarktika Deniz Canlı Kaynaklarını Koruma Sözleşmesi (CCAMLR) ve 1988 tarihli Antarktika Doğal Kaynak Aktiviteleri Düzenleme Sözleşmesi (CRAMRA) bu eksiklikleri gidermek amacıyla oluşturulmuştur. Canlı kaynakların korunmasına yönelik oluşturulan CCAMLR (Commission for the Conservation of Antarctic Marine Living Resources) halen daha geçerliliğini korurken; CRAMRA yürürlüğe girmeden kaldırılan ölü bir metin olmuştur. 1959 tarihli Antarktika Antlaşması'nda doğal kaynak aktivitelerinin düzenlenememesinden kaynaklı eksikliğin giderilmesi amacıyla oluşturulan CRAMRA, enerji faaliyetlerinin çevrenin korunması şartiyla sürdürülebileceğini belirten bir metindir (Vigni, 2000: 513). Ulus devletler doğal kaynakların kullanımı ve çevrenin korunması 
hususunda ikilemde kalmışlar ve sonuç olarak enerji faaliyetlerinin yasaklanarak çevrenin korunması hususu ağır basmıştır. Bu şartlar altında ortaya çıkan 1991 tarihli Madrid Protokolü, Kıta’nın şimdiki statüsünün belirlenmesinde önemli rol oynamıştır.

1991 tarihinde Madrid Protokolü olarak da bilinen Antarktika Antlaşması Çevre Koruma Protokolü'nün kabulü ile Kita üzerinde tüm insanlık yararına maden çıkarmak yasaklanmıştır. Taraf ülkeler bu Protokol ile birlikte maden arama ve kullanma haklarından feragat etmişlerdir ve bu protokol, Antarktika Kıtası'nın insanlığın ortak mirası olması konusunda dönüm noktasi olmuştur (The Protocol on Environmental Protection to the Antarctic Treaty, 1991). Protokolün 7. Maddesi açık bir şekilde Antarktika'da bilimsel araştırmalar dışında maden kaynaklan ile ilgili tüm faaliyetleri yasaklamaktadır (Protocol on Environmental Protection to the Arctic Treaty, 1991).

1998 yllında yürürlüğe giren protokolün Giriş bölümünde Antarktika çevresinin ve ona bağlı ya da bağımlı ekosistemlerin korunması insanlığın ortak çıkarı olarak benimsenmiştir (The Protocol on Environmental Protection to the Antarctic Treaty, 1991). Protokolün 2. Maddesi Antarktika'yı barış ve bilime adanmış doğal rezerv alanı olarak kabul etmektedir. Bu bağlamda yürütülen ya da planlanan faaliyetlerde bölgedeki iklim veya hava modellerine olumsuz etki etmekten, hava ve su kalitesini bozmaktan, atmosferik, karasal, buzul ya da deniz çevresinde göze çarpan değişimlere neden olmaktan, fauna ve flora içindeki türlerin dağılımı, sayıları ve üremelerine yıkıcı etkiden, tehlike ya da tehdit altındaki türlerin durumunu tehlikeye düşürmekten, biyolojik, bilimsel, tarihi, estetik ya da eldeğmemişlik (wilderness) bakımından dikkat çeken bölgelerde bozulmaya neden olmaktan ya da bu bölgeleri riske atmaktan kaçınılması öngörülmektedir (Madde 3.2.b). Protokol'ün 50 ylllık bir süre için geçerli olması nedeniyle, 2048 sonrasında bölgenin ticari faaliyetlere açılması gibi bir risk belirmektedir. Gelecekteki bu belirsizliğe rağmen Antarktika Antlaşmalar Sistemi, bölgedeki insan kaynaklı faaliyetleri kısıtlayarak, çevresel korumaya önemli bir katkı sağlamaktadır.

ATS'nin yaratmış olduğu etkinliği sağlayacak başka bir uluslararası yönetişim sistemi bulunmamaktadır (Young, 2017: xiv). Ancak bu durum ATS'nin kusursuz bir sistem olduğunu kanitlamasa da, sistemin uluslararası barışa, bilimsel bilgi alışverişine, kaynak yönetimine ve uluslararası ahlâka olan katkısı yadsınamaz (Young, 2017: xv). Kita üzerindeki bu yönetişim biçimi ile Antarktika Kıtası, insan aktivitelerinin sürdüğü dünya üzerindeki tek barışçl kıta olma özelliğini korumaktadır. 


\subsection{Kuzey Kutup Bölgesi'nin Hukuki, Ekonomik ve Siyasi Statüsü}

$66^{\circ} 33^{\prime \prime}$ Kuzey enleminin üstünde kalan alanlar için kullanılan Kuzey Kutbu ya da Arktik Dairesi ifadesi, Kutup Bölgesi'nin genişliğini daha güneye kaydırmak amacıyla oluşturulmuş hayali bir hattır. Bu hatta güneş yaz ortasında bir gecede ufukta aşağı batar ama aslında tam olarak batma işlemi gerçekleşmez. Bu olay, 'gece yarısı güneşi' tabiri ile ifade edilir (Vitebski, 2015: 2). Daha kuzeyde ise yaz aylarında güneş hiç batmaz ve aylarca ya da haftalarca yaz geceleri aydınlık geçer. Kış aylarında ise Arktik Dairesi çizgisi üzerinde sadece bir gün hiç güneş doğmaz. Daha kuzey bölgelerde ise güneş aylarca doğmadan ve kış oldukça soğuk geçer (Vitebski, 2015: 2). Kışın tek 1şık 'Aurora'lardan yani kutup 1şılarından gelmektedir (Attenborough, 2011). Arktik Dairesi'ni belirleyen bu hayali hattın altında ve üstünde kalan alanların iklimsel koşulları ve bu koşullar sonucu ortaya çıkan coğrafya, birbirinden farklıdır.

Kuzey Kutup Bölgesi'nin hukuki, siyasi ve ekonomik statüsünün anlaşılabilmesi için o bölgenin coğrafik yapısının irdelenmesi gerekmektedir. Arktik Bölgesi dünya yüzeyinin \%6'sını kaplamaktadır ve bu alanın da 1/3'ü topraktır (Kriz ve Chrastansky, 2012: 116). Kanada, Danimarka, Finlandiya, İzlanda, Norveç, Rusya, İsveç ve Amerika Birleşik Devletleri Arktik ülkesi olarak anılmaktadır (Arctic Council Member States, 2015). Arktik Bölge'nin 3'te 2'sini oluşturan deniz alanları bölge ülkelerinin çatışma ve işbirliği potansiyellerinin olduğu alanlar olarak anılmaktadır. Kuzey Kutbu'nun donmuş bir okyanus olan Arktik Okyanusu olarak ifade edilmesi sonucu o okyanus üzerinde bulunan kara parçaları ve deniz sınırları önem kazanmıştır. Arktik Okyanusu'na Kanada, Danimarka, Norveç, Rusya ve Amerika Birleşik Devletleri olmak üzere beş adet ülkenin kıyısı bulunmaktadır ve bunlar Arktik Beşlisi olarak ifade edilmektedir (Kuersten, 2016: 390). Okyanusa kıyısı olmayıp Kuzey Kutbu ülkesi olarak geçen diğer ülkeler ise İsveç, Finlandiya ve İzlanda'dır (Byers, 2013: 2).

İklim değişikliğinin etkileri ile birlikte eriyen buzullar sonucunda, Arktik Okyanusu üzerinde daha önce ulaşlmayan bölgelere erişim artmıştır. Gelişen teknolojik imkânlarla birlikte ülkeler, deniz yetki alanlarını genişletmeye çalışış ve bu durum beraberinde çatışma potansiyelini doğurmuştur. Arktik Okyanusu'nda bulunan canlı ve cansız doğal kaynaklar bu genişletme çalışmalarında önemli bir rol oynamıştır. Arktik Okyanusu'nda bulunan doğal kaynaklara ilişkin en önemli belge 2008 y1lında yayınlanan ABD Jeolojik Araştırma Merkezi'nin raporudur. Bu rapor uyarınca, Arktik Dairesi'nin kuzeyinde kalan 33 coğrafik merkezde 90 milyar varil petrol, 1,669 trilyon kübik fit doğal gaz ve 44 milyar varil likit doğal gaz bulunmaktadır (USGS Fact Sheet, 2008). Bu doğal kaynakların yanında kalay, kömür, manganez, altın, nikel, kurșun, platin, çinko, elmas ve balık rezervleri bulunan Arktik Bölgesi'nde (Boyd et al., 2016: 9-10), ülkesel 
sınırların ötesinde kalan; yani hiçbir ülkenin egemenliğinde olmayan deniz alanları dikkat çekmektedir.

Arktik Bölgesi, Antarktika'nın aksine insanlığın ortak miras1 olarak nitelendirilmemiş, bölge ülkelerinin egemenlik hakları altında bırakılmıştır. Ülkesel sınırların içinde bulunan buzla kaplı kara ve deniz alanların kullanımı ve korunmasi tamamen egemen ulus devlete aittir. Egemenlik sinırlarının ötesinde kalan alanlar olan kara parçalarının ve deniz alanlarının hukuki statüsü çatışma halindedir. Arktik Okyanusu üzerindeki çatışma alanlarını; kıta sahanlığı ve münhasır ekonomik bölge (MEB) üzerindeki çatışmalar, geçitler ve boğazlar üzerindeki çatışmalar ve kara parçaları üzerindeki çatışmalar olarak sıralayabiliriz (İnan Şimşek, 2016: 99). Bu çatışma alanları Arktik Beşlisi'nin aralarında yaşanan deniz yetki alanları sorunlarını içermektedir.

Kita sahanlı̆̆1 ve münhasır ekonomik bölge üzerinde yaşanan sınır anlaşmazlıklarında dikkat çeken bölgeler Bering Denizi, Beaufort Denizi, Barents Denizi, Lomonosov Sirtı ve Alpha-Mendeyelev Sirtı olarak ifade edilmektedir. Bu bölgelerde yaşanan anlaşmazlıklara kıyıdaş ülkeler, Birleşmiş Milletler Deniz Hukuku Sözleşmesi (BMDHS) uyarınca çözüm bulmaya çalışmaktadırlar. Geçitler ve boğazlar sorununa bakıldığında da Kuzeybatı Geçidi, Kuzeydoğu (Kuzey Deniz Rotası) Geçidi ve Bering Boğazı üzerindeki çatışmalar ön plana çıkmaktadır. Tıpkı kıta sahanlığı ve MEB üzerinde yaşanan sorunlar gibi bu alanlardaki sorunlar için ulus devletler BMDHS'ni referans kaynak olarak kullanmaya çalışmaktadırlar. Svalbard ve Hans Adası üzerinde yaşanan egemenlik anlaşmazlıklarında da ülkeler BMDHS'den yararlanmakta; uluslararası hukukun yaratmış olduğu kurum ve kurallar Arktik Okyanusu'nu çevreleyen ülkelerin işbirliği arac1 olarak karşımıza çıkmaktadır (İnan Şimşek, 2016: 99-108).

Arktik Bölge'nin hukuki ve politik statüsü, İngiliz Okulu'nun ortaya koymuş olduğu yaklaşımla detaylı olarak anlatılacaktır. Bu sebepten ötürü bu bölümde bölge üzerindeki işbirlikleri ele alınmamış genel bir çerçeve sunmak amaçlanmıştır. İki Kutup üzerindeki ulus devletlerin faaliyetlerinin inceleneceği sonraki bölümün amac1, uluslararası toplumun çoğulcu mu yoksa dayanışmacı bir yaklaşım içerisinde mi hareket ettiğini irdelemek olacaktır. Bu amaçla mevcut işbirlikleri incelenecek, mevcut ve potansiyel uyuşmazlıklar aktarılacaktır. İngiliz Okulu teorisinin bölgelere uyarlanması amaciyla kurumlarından yararlanılacak ve tarihsel yorumsamacı metodoloji bu perspektifte araç olacaktır.

\section{Uluslararası Toplumun Kutup Politikalarındaki Çoğulcu- Dayanı̧̧macı Perspektifi}

İngiliz Okulu'nun içinde ortaya çıkan çoğulcu-dayanışmacı ayrımı, Kutup Bölgeleri'nin geleceğine dair varsayımda bulunmamıza yardımcı olacaktır. $\mathrm{Bu}$ 
amaçla birbirine coğrafik olarak benzeyen iki Kutup Bölgesi'nin tarihsel perspektifte geçirmiş olduğu evrim ele alınmalı ve bu gelişim sürecinin düzen-adalet ayrımında ne noktada olduğu aktarılmalıdır. Bu amaçla ulus devletlerin o bölgelerdeki faaliyetleri ele alınacak, uluslararası toplumun genişlemesi, dönüşümü irdelenmeye çalışılacaktır.

\subsection{Uluslararası Toplumun Güney Kutbu Politikaları: Çoğulculuktan Dayanı̧̧macılığa İdeal Düzen Tartışması}

Amerika Birleşik Devletleri'nin politik baskıları sonucu Antarktika Kıtası üzerinde yedi ülkenin egemenlik iddiaları dondurulmuş (Berkman, 2011: 17) ve Kıta üzerindeki faaliyetler, Antlaşmalar Sistemi ile sağlanmıştır. Antarktika Kitası'nda maden arama ve işletme de 2048 yllına kadar yasaklanmıştır. Antarktika Antlaşması ve bu Antlaşma'nın ardından ortaya çıkan çeşitli antlaşmalara taraf 29'u İstişari Devlet ve 24'ü İstişari Olmayan Devlet olmak üzere 54 devletin (Antarctic Treaty Parties) kita üzerinde sadece barışçıl amaçlarla bilimsel faaliyetlerine izin verilmiştir. Antarktika Antlaşmalar Sistemi’nin yaratmış olduğu bu hukuki düzen, Dünya üzerindeki yönetişim sistemleri arasında en farklı olanıdır ve kendisine eklemlenen ulus devletlere ayrıcalıklar kazandırmaktadır.

ATS'nin yaratmış olduğu düzen kusursuz değildir ve bu sisteme yönelik birtakım eleştiriler dile getirilmektedir. $\mathrm{Bu}$ eleştiriler Antlaşma'nın imzalandığ1 1959 ylına kadar geri gitmektedir. 1959 Antarktika Antlaşması'nın mevcut egemenlik iddialarını dondurması ve başka egemenlik iddialarının da kabul edilmeyeceği anlayışının, ABD'nin ve SSCB'nin baskılarıyla ortaya çıtı̆ğ dile getirilmektedir (Triggs, 2008: 52). ABD ve SSCB'nin Antarktika Kitası'nda hâlihazırda egemenlik iddiasının bulunmaması (ne coğrafi yakınlık ne de keşifler aracillğıyla), Antlaşma sayesinde kıta üzerinde bilim üssü kurarak gelecekte egemenlik iddiasında bulunabilecekleri inancını doğurmuştur (Triggs, 2008: 53). Aynı zamanda Uluslararası Jeofizik Yılı sonrasında Antlaşma'ya taraf 12 ülkenin toplam 60 adet bilim üssü kurması da gelecekte ulus devletlerin egemenlik iddialarında bilimi kullanacağ1 endişelerini yaratmıştır (Anderson, 2008: 58).

Amerika Birleşik Devletleri'nin ve SSCB'nin Antarktika Kıtası üzerindeki mevcut egemenlik iddialarını reddetmelerinde öne sürdükleri gerekçe; bu iddialarda bulunan ülkelerin etkili bir yerleşimlerinin bulunmaması tezine dayandirilmaktadir (Ross, 2003: 3). 1948 yllinda ABD tarafindan Antarktika'nın statüsünün belirlenmesi konusunda iki değişik bakış ortaya konmuştur. İlki, toprak iddialarının belirlenmesi için bir moratoryumun düzenlenmesi ki bu moratoryum da Antarktika'nın Birleşmiş Milletler'in (BM) yönetimi altında güvenilir bir şekilde yönetilmesi anlamına gelmekteydi (Maquieira, 1986: 52). Bu sav, egemenlik iddiasında bulunan ülkelerin aralarındaki sorunları çözmeyi hedeflerken aynı zamanda egemenlik iddiasında bulunan ülkeler ile hiçbir egemenlik iddiasında bulunmayan 
ülkelerin aralarındaki sorunları da çözmeyi amaçlamıştır (Ross, 2003: 5). Bu öneri, SSCB'nin Antarktika'da herhangi bir egemenlik iddiasında bulunmasını önlemeye yönelik olduğu ve $\mathrm{BM}$ aracilığıla $\mathrm{ABD}$ ve Büyük Britanya'nın Antarktika yönetimine sürekli müdahale edebileceği eleştirileri çerçevesinde kabul edilmemiştir. ABD bu önerisinin reddedilmesinin ardından müşterek egemenlik öngören teklifini sunmuş, ancak bu çok taraflı egemenlik anlayışı içerisine SSCB'yi dâhil etmemiştir. Bu öneriye özellikle Arjantin ve Şili'den olumsuz görüş gelmiştir (Ross, 2003: 5).

1950'li yllar Antarktika için bir rejim arayışı içerisinde geçmiştir. 1956 yllında Yeni Zelanda'nın Antarktika'nın bir dünya toprağı olması ve Birleşmiş Milletler altında yönetilmesi önerisi de reddedilmiştir. Aslında 1950'de devam eden Soğuk Savaş yıllarında Güney Kutbu'nun, süper güçlerin görünmeyen meydan savaşına sahne olduğu dile getirilmektedir (Ross, 2003: 6). SSCB'nin Antarktika'nın geleceği konusunda yaşamış olduğu endişelere, $\mathrm{ABD}$ onu dışlayarak karşlık vermeye çalışmıştır. ABD ve SSCB arasında güç mücadelesine sahne olan bu yullarda özellikle kıtanın askerileşmeden uzak olmasına özen gösterilmeye çalışılmıştır. Ayrıca dünyanın herhangi bir bölgesindeki kara parçasının statüsünün belirlenmesinde $A B D$ ve SSCB'nin birlikte söz sahibi olduğu gerçeği de ortaya konmuştur. ABD, SSCB'yi dışlayamamış ve 1959 tarihinde Antarktika Antlaşması Konferansı bu şartlar altında gerçeklemiştir. Ulus devletlerin böylesine bir antlaşmayı imzalayıp, Kıta'nın tüm insanlık adına korunmasına aracılık etmeleri de zamanın ruhu ile ilişkilendirilmiştir. Antarktika Antlaşması'nın Soğuk Savaş şartlarında olgunlaşması ve imzalanması, Kıta'nın barışçıl amaçlarla korunması amacından çok, küresel bir rekabetin önüne geçmeye çalışıldığını akıllara getirmiştir (Triggs, 2008: 54). 1959 Antarktika Antlaşması ile bir nevi güç dengesi kurulmaya çalışılmış, Soğuk Savaş'in iki süper gücünü ortak bir noktada buluşturmuştur.

Uluslararası toplum; güçler dengesi, uluslararası hukuk, diplomasi, savaş ve büyük güçler arasındaki uyum kurumları araciloğılla, merkezi bir otoritenin yokluğunda o sistemin üyelerinin varllğının garanti altına alınmasını, düzenin sağlanıp şiddetin sınırlandırılmasını ve bu şekilde adaletin sağlanmasını amaçlamaktadır (Ağkaya, 2016: 1061). Bu anlayıştan hareketle, Antarktika'nın ABD ve SSCB gibi iki büyük gücün çekişmesine sahne olduğunu ve ardından uluslararası hukukun yaratmış olduğu kurumlar aracılı̆̆ılya aralarında denge kurup anarşiden kaçındıklarını söylemek yerinde olacaktır. Antarktika Antlaşması'nın yaratmış olduğu güç dengesi, İngiliz Okulu'nun birincil kurumlarından olan diplomasi ile oluşturulmaya çalışılmış ve büyük güçler arasında denge kurulmuştur. Ortaya çıkan ikincil kurum örneklerinden sayılabilecek olan Antarktika Antlaşması ile kıtada uluslararası toplum düşüncesi gelişmeye başlamıştır. 
1959 tarihli Antarktika Antlaşması 14 maddeden oluşmaktadır ve bu antlaşmaya taraf devletlere ithafen oluşturulmuştur. Bu durum Antarktika Antlaşmalar Sistemi'ne yönelik en büyük eleştirilerin yapılmasına sebebiyet vermektedir. Antarktika üzerinde faaliyet yürütülmesinde yetkili devletler, antlaşmaya taraf devletlerdir ve kıtanın geleceğini onlar belirlemektedir. Bu durum taraf devletlerin ellerinde orantısız bir gücü barındırdıkları yönünde eleştirilere sebebiyet vermektedir (Vicuna, 2008: 68). Hatta bu durum, Antlaşmaya taraf olmayan bazı ülkeler tarafından, gelişmiş ülkelerin yeni kolonileşme çabaları olarak dile getirilmiş ve kıta üzerindeki tüm ekonomik ve çevre faaliyetlerinin insanlığın ortak mirası ilkesi çerçevesi içerisinde olması gerektiği dile getirilmiştir.

İnsanlığın ortak mirası ilkesi, dünya üzerindeki uluslararası toplum anlayışını kökünden değiştirecek bir uygulamadır. İngiliz Okulu'nun dünya toplumu anlayışını akıllara getiren bu düşünce çerçevesinde Kıta; egemenlik iddialarının reddedildiği, bütün ulusların temsilcilerinin buradaki kaynakların yönetişiminde söz sahibi olacağı, bölgede çıkan kaynaklardan elde edilen kazançların tüm uluslarca paylaşılacağı, sadece barışçıl amaçlarla kullanımın serbest olduğu ve silahlanmaya izin verilmeyeceği ve gelecek nesillerin yararı düşünülerek korunacağ1 bir alana dönüşmüştür (Başlar, 1998: xx-xi). Antarktika Antlaşması insanlığın ortak mirası ilkesini benimsemiş olsa dahi Antlaşma'nın taraf devletlerin rızasına bırakılmış olması, Kıta'da dünya toplumu varlığından uzaklaşıldığını ve Kıta'nın aslında insanlığın ortak mirası olmadığını ortaya koymaktadır.

Antarktika meselesi BM Genel Kurulu'na 29 Eylül 1982 y1lında Malezya Başbakanı Dr. Mahatir bin Mohamad tarafindan sunulmuştur (Hayashi, 1986: 275). Mohamad, yerleşimi ve yerli halkı olmayan dünyanın en büyük toprak parçası olarak geçen Antarktika Kıtası'na uluslararası toplumun dikkatini çekmeye çalışmış ve 1982 tarihli BM Deniz Hukuku Konferansları sırasında da aristokratik kulübe ${ }^{6}$ yönelttiği eleştirilerle birlikte bu sistem değişime uğramaya başlamıştır (Başlar, 1998: 247). Antlaşmaya o dönemde taraf olmayan Malezya Başbakanı, Antarktika'nın tüm insanlı̆̆ın yararı için potansiyel barındıran ortak çıkara dayalı bir alan olduğunu belirtmiş ve uluslararası toplumun dikkatini bu ortaklığa çekmeye çalışmıştır (Hayashi, 1986: 276). Malezya Başbakanı bu düşüncelerini Bağlantısızlar Hareketi toplantılarında da 1983 yılından itibaren dile getirmeye başlamıştır (Hayashi, 1986: 276).

${ }^{6}$ Antarktika Antlaşma'sı yürürlüğe girdiği tarihte taraf olan 12 ülke isterlerse Antlaşmayı feshedebilme ya da genişletebilme yetkisine sahip bulunmaktaydı. Bütün bu yetkileri insanlık adına hareket edebilme iddiasını ortaya koyarak kullanabilmekteydiler. Bu nedenle 1959'dan 1982 yılına kadar olan dönemi Kemal Başlar, "aristokrasi kulübü” olarak adlandırmıştır (1998: 245). 
Malezya Başbakanı'nın eleştirileri Antarktika Antlaşması İstişari Devletleri'ne yönelik olmuştur. Yerleşimin olmadığı bir kıta için yapılan mevcut antlaşmanın çağdışı olduğunu belirten Mohamad, Antarktika'da gelecekte ortaya çıkacak kaynaklardan sadece bu devletlerin yararlanamayacağını aksine potansiyel kaynakların tüm insanlığa ait olması gerektiğini belirtmiştir (Tepper ve Haward, 2005: 114). Ayrıca Antarktika Antlaşması'nın kolonileşme sisteminin yasal karşıllı̆̆ olduğunu belirterek seçilmiş birtakım devletlere münhasır yetkiler kazandırdığını ifade etmiştir (Tepper ve Haward, 2005: 114). BM Deniz Hukuku Konferansları sirasinda yaşanan bu gelişmeler, Antarktika rejimi konusunda bir dönüm noktası olmuştur (Başlar, 1998: 247). Malezya Başbakanı söylemlerini girmiş olduğu her ekonomik ve politik platformda dile getirmeye başlamış ve Antarktika'nın gelişmekte olan ülkeleri de kapsayarak insanlığın ortak mirası statüsüne taşınması konusunda söylemlerde bulunmuştur. Malezya, Antarktika Antlaşması'na 2011 yılında taraf olmuş olsa da, o tarihe kadar Başbakan Mohamad önderliğinde Antarktika politikalarını sürdürmeye devam etmiştir (Tepper ve Haward, 2005: 113).

Malezya'nın bu girişimi, uluslararası toplumun ideolojisine bir meydan okuma olarak nitelendirilmektedir. Tarihsel bakış açısıyla değerlendirildiğinde Linklater'ın ifade ettiği Batı'ya meydan okuma olarak nitelendirilebilecek bu olay, Antarktika üzerinde söz sahibi olacak uluslararası toplumun genişlemesine giden yolu açmıştır. Antarktika üzerinde status quo olarak devam eden bu rejimin demokratik olmadığı sorgulanmaya başlamış ve rejime dâhil olan İstişari Devletlerin tüm insanlık adına değil, sadece kendi çıkarları için hareket ettikleri yönünde eleştirilerin sayısı yükselmiştir (Tepper ve Haward, 2005: 115). Bu süreçten sonra İstişari Devlet üye sayısında artış yaşanmıştır. İstişari Devlet sayısı Üçüncü Dünya Ülkeleri olarak adlandırılan Brezilya, Çin, Hindistan gibi ülkelerle 22'ye yükselmiş ve standartlar yumuşatılmıştır (Başlar, 1998: 248). Antarktika Antlaşmalar Sistemi ile oluşan uluslararası toplum genişlemeye başlamış ve 1991 yilına kadarki dönemde Antlaşma'ya eklemlenen ülkelerle birlikte ATS, dünya nüfusunun 3/4'ünü içinde barındırır hale gelmiştir (Başlar, 1998: 248).

Antarktika Antlaşmalar Sistemi'nin dönüşümü ise 1991 tarihinde Madrid Çevre Koruma Protokolü'nün de kabulü ile sağlanmış ve Kıta üzerinde bilimsel faaliyetler dışında maden çıkarmak da dâhil diğer faaliyetler yasaklanmıştır (1991 Madrid Protokolü, Madde 7). Taraf ülkeler bu Protokol ile birlikte maden arama ve kullanma haklarından feragat etmişlerdir. Madrid Protokolü Antarktika Kıtası'nın insanlığın ortak mirası olması konusunda bir dönüm noktasını oluşturmaktadır. Antarktika Antlaşması'nın ortaya koymuş olduğu 14 madde ile yaratmış olduğu rejimin, adalet ve eşitlik sunmada başarısız olması sonucu ortaya çıkan eksiklik Madrid Protokolü ile giderilmeye çalışılmışırı. Çevre koruma prosedürleri dikkate alındığında bir Dünya Parkı anlayışı ile hareket edildiği ve aslında de facto olarak insanlığın 
ortak mirası anlayışının kabul edildiği görülebilmektedir (Başlar, 1998: 248). $\mathrm{Bu}$ protokol ile birlikte Antarktika Kitası üzerinde uluslararası demokrasi anlayışının gelişiminin hız kazandığı dile getirilmekte ve Antarktika'nın geleceğinde tüm insanllğın söz sahibi olacağı hususunda beklentiler artmaktadır. Bütün bu gelişmeler dayanışmacı paradigmanın Kıta üzerindeki hakimiyetini arttırmakta ve ulus devletlerin daha adil bir düzen oluşturmaya çalıştıklarını göstermektedir. 1958 yılında oluşturulan Antarktik Araştırmaları Bilim Komitesi (SCAR)'nin İstişari Devletler'e tavsiye niteliğinde bilgiler vermesi ve onların Antarktika politikalarını etkilemesi de ulus devletin yanında hükümet dış1 örgütlerin de uluslararası topluma eklemlendiğini ortaya koymakta ve Kıta'daki rejimin dayanışmacı yönünü desteklemektedir.

\subsection{Uluslararası Toplumun Kuzey Kutbu Politikalarında Düzen - Adalet İkilemi}

Kuzey Kutup Bölgesi'nde uluslararası toplumun politikalarının dikkat çektiği alan Arktik Okyanusu ve çevresidir. Ulus devletlerin egemenlik alanları ötesinde kalan ve birtakım çatışmaların yaşandığı Arktik Okyanusu üzerinde uluslararası toplumun kurumları ve aktörleri faaliyet göstermektedir. Arktik deniz buzunun iklim değişikliğinin etkisiyle erimesi sonucu ortaya çıkan potansiyel doğal kaynaklar ve yeni ulaşım yolları üzerinde hâkimiyet kurma arayışı, sadece Arktik ülkelerinin değil, Arktik dışı ülkelerin de dikkatini çekmektedir. Yaşanan gelişmelere paralel olarak bölgede askerileşmenin hız kazandığı görülmekte ve çatışma ihtimalleri ortaya çıkmaktadır.

Soğuk Savaş dönemi boyunca Kuzey Kutup Bölgesi bir tarafta bölgenin neredeyse yarısını elinde tutan SSCB ile diğer tarafta NATO ülkeleri (Kanada, Danimarka, İzlanda, Norveç, ABD) arasında ikiye bölünmüş, İsveç ve Finlandiya da tarafsızlıklarını belirterek iki blok arasında kalmışır (Young, 2004: 3). Young'a göre, Dünya nüfusunun \%15'inin bulunduğu ülkelerin Arktik Bölgesi'nde yer alması ve bu ülkelerin Ortadoğu ve Asya ülkelerine nazaran politik, ekonomik ve siyasi gelişimin merkezinde yer alan ülkelerin olmasi; Arktik Bölgesi'ndeki gelişmelerin de Dünya'nın diğer bölgelerine kıyasla farklı olacağının kanıtıdır (2004: 3). Güney Kutup Bölgesi’nin aksine Kuzey Kutup Bölgesi'nde yerleşimin olması da bölgedeki hukuki, politik ve siyasi gelişmelerin farklılaşmasına yol açmaktadır. Bölge ülkelerinin yanı sıra Inuit gibi yerli haklar da Kuzey Kutup politikaları hakkında söz sahibi olmakta ve yerli halklar da Bölge aktörleri arasında yer almaktadır (Uysal Oğuz, 2017: 121). Arktik Bölge'de çoğulcuların belirttiği gibi sadece ulus devlet merkezli bir sistem yer almamakta aynı zamanda bir takım hükümet dışı kuruluşlar da söz sahibi olabilmektedir.

Arktik Bölgesi’nin çok aktörlü bir yapıda olması, Bölge'nin işbirliğine açık olmasını sağlamış ve gerek ikili gerekse çok taraflı işbirliği girişimleri Bölge'de kendini göstermiştir. Bir taraftan çevre koruma adına atılan işbirliği 
girişimleri mevcutken, diğer taraftan hegemonik amaçlarla yürütülen ikili ya da çok taraflı işbirliği girişimleri bulunduğundan; Arktik'teki mevcut işbirliği girişimleri uluslararası toplumun düzen-adalet ikileminin sorgulanmasina yol açmıştır. Uluslararası toplumun Arktik politikalarını bu amaçla ikiye ayırmamız yerinde olacaktır. Düzen kurmayı amaçlayan İngiliz Okulu'nun çoğulcu kanadının belirtmiş olduğu şekliyle oluşturulan uluslararası toplum girişimleri ve dayanışmacı ekolün öngördüğü adalet arayışı içerisinde olan uluslararası toplum faaliyetleri olarak ikiye ayrrlan bu işbirliği girişimleri uluslararası toplumun, Bölge'de düzen-adalet dengesi mi kurmaya çalıştı̆̆1 sorunsalını akıllara getirmektedir. Ortaya çıkan bu sorunsalın çözümü için düzen kapsamında değerlendirilebilecek Arktik Okyanusu'ndaki deniz yetki alanlarında yaşanan sınır çatışmaları için oluşturulan işbirliği girişimleri aktarılmaya çalışılacaktır. Ayrıca çevre koruma faaliyetleri adına oluşturulan adalet anlayışının daha ağır bastığı işbirliği girişimleri de aktarılacak ve bu girişimlerin düzen-adalet dengesini kurup kurmadığı anlaşılmaya çalışlacaktır.

Soğuk Savaş dönemi boyunca iki kutbun düşmanlıklarının yerleştiği, denizaltıların devriye gezdiği ve stratejik bombaların konuşlandırıldığı alan olan Arktik Okyanusu (Kriz ve Chrastansky, 2012: 113), Soğuk Savaş sonras1 dönemde işbirliğinin merkezi haline gelmiştir. Soğuk Savaş sonrası ilk işbirliği girişimi Arktik Çevre Koruma Stratejisi (AEPS) olmuştur ve Arktik Bölgesi'nde bulunan sekiz ülkenin yanında BM'ye bağlı birkaç kurum ile Almanya, Birleşik Krallık, Polonya gibi ülkeler ile yerli halklara ait örgütler de bu işbirliğine dâhil olan aktörlerdir (Arctic Environmental Protection Strategy, 1991: 1). AEPS bünyesinde 1996 Ottowa Deklarasyonu ile oluşturulan bölgedeki en üst düzey hükümetlerarası forum olan Arktik Konseyi (The Arctic Council: A Backgrounder, 2018) ile Arktik Bölgesi'nde uluslararası işbirliği ve koordinasyon sağlanmaya çalısıllmaktadır (İnan, Şimşek, 2016: 112). Arktik Konseyi'nin 6 adet çalışma grubu vardır. Bunlar; Arktik Bölgesi Gözlem ve Değerlendirme Programı (AMAP), Sürdürülebilir Kalkınma Çalışma Grubu (SDWG), Arktik Deniz Çevresini Koruma Grubu (PAME), Arktik Fauna ve Flora Koruma (CAFF), Acil Önlem, Hazırlık ve Müdahale (EPPR), Arktik Kirleticileri Eylem Programı (ACAP) olarak siralanmaktadır (Arctic Council Working Groups, 2015).

AEPS ve sonrasında oluşturulan Arktik Konseyi’nin ele aldığı konulara ve işleyişine baktığımızda, bağlayıcılığı olmayan taahhüt niteliğinde bir metin ve ekosistemin korunması, sürdürülebilir kalkınma politikaları uygulamayı amaçlayan tavsiye niteliğinde kararlar alan bir kurum karşımıza çıkmaktadır (The Arctic Council: A Backgrounder, 2018). Konsey'in kararlar1 her ne kadar bağlayıcı olmasa da 8 Arktik ülkesi için bağlayıcı olan 3 adet antlaşmanın oluşması için bir forum hizmeti sağlamıştır. Bu antlaşmalar; Arktik Havacılık ve Denizcilik Arama Kurtarma İşbirliği Antlaşması (2011), Arktik Denizi'ndeki Petrol Kirliğini Önleme ve Müdahale İşbirliği 
Antlaşması (2013) ve Uluslararası Arktik Bilimsel İşbirliğini Geliştirme Antlaşması (2017) olarak sıralanabilir (The Arctic Council: A Backgrounder, 2018). Arktik Konseyi'nin yapısı ve aracılık etmiş olduğu antlaşmalara baktığımız zaman ortaya çıkan tablo; bilimsel bilgi alışverişi, çevre koruma, sürdürülebilir kalkınma ve insan güvenliği konularında dayanışmacı bir yaklaşımın benimsendiği ve uluslararası toplumun adalet ve etik değerler üzerine eğildiği şeklindedir.

Arktik Bölge'de tüm insanlığ1 ilgilendiren çevre koruma, bilimsel bilgi alışverişi, sürdürebilir kalkınma ve insan güvenliği konularında çok aktörlü uluslararası işbirliği örnekleri görülürken, diğer taraftan ulus devletlerin güç mücadelesi devam etmekte ve bazı konularda işbirliği arayışı kısıtlı kalmaktadır. Deniz yetki alanları sorunu işbirliğinin kısıtlı olduğu alanlar olarak görülmekte ve Bölge'deki deniz alanlarındaki uyuşmazlıklar ${ }^{7} 20$. yüzyılın başlarına kadar götürülebilmektedir. ABD ve SSCB arasında Bering Denizi üzerinde yaşanan deniz yetki sınırlandırılması sorunu 1893 yılına kadar götürülebilir (The Chicago Sunday Tribune, 1893: 9). Arktik Okyanusu ile Pasifik Okyanusu arasındaki tek geçit olan Bering Boğazı'nın statüsü de Bering Denizi'nin yetki alanları sorunu da iki ülke arasında zaman zaman çatışmanın şiddetinin yükselmesine yol açmıştır (Berkman et al., 2016: 187). ABD ve SSCB arasındaki bu sorunlu bölge için uluslararası dokümanlarda "Bering Boğazı Bölgesi" ifadesi kullanılmakta ve Bering Denizi, Bering Boğazı ve birtakım kara alanları bu bölgeye dâhil edilmektedir (Joint Statement in the Bering Strait Region, 2011). Bu bölge için küresel, bölgesel ve ikili birtakım antlaşmalar ve işbirliği girişimleri göze çarpmaktadır (Berkman et al., 2016: 191-192) ve bu durum bölgenin uluslararası toplumun düzen oluşumuna açık olduğunun en büyük göstergelerinden biridir. Bering Denizi üzerinde 2013 yılında iki ülke arasında imzalanan işbirliği antlaşması da halen daha geçerliliğini korumakta ve Bölge üzerindeki düzenlemelerle birlikte özellikle Bering Boğazı'nın uluslararası geçit statüsü korunmaktadır (Byers, 2013: 157). ABD'nin 1982 tarihli BM Deniz Hukuku Sözleşmesi'ne taraf olmamasi ${ }^{8}$ dolayısıyla herhangi bir uyuşmazlık halinde ise bölgede örf ve adet hukukunun geçerli olacağını belirtmek yerinde olacaktır (Owens, 2011: 96).

Bering Denizi'nin yanında Barents Denizi ve Beaufort Denizi'nde de deniz yetki alanları sorunları baş göstermektedir. Beaufort Denizi'ndeki uyuşmazlık, iki müttefik ülke olan $\mathrm{ABD}$ ve Kanada arasında baş

\footnotetext{
7 Bu çalışmada Arktik Okyanusu'nda bulunan deniz yetki alanları sorununa detaylı olarak değinilmeyecektir. Çalışmanın amacı açısından uyuşmazlıklar üzerindeki işbirlikleri değerlendirmeye alınacaktır. Arktik Okyanusu'ndaki deniz yetki alanları sorunu hakkında detaylı bilgi için: İnan Şimşek, 2016: 93-118.

8 Arktik Okyanusu'nu çevreleyen 5 ülkeden 4'ü (Kanada, Danimarka, Norveç ve Rusya) 1982 tarihli BM Deniz Hukuku Sözleşmesi’ni kabul etmiştir. Sadece ABD bu sözleşmenin tarafı değildir (Weber, 2009: 656).
} 
göstermektedir ve iki ülke de kıta sahanlığı iddiaları ile sınırlarını genişletme arayışı içerisine girmişlerdir (Kolak, 2011: 13). Ancak buzul koşulların hüküm sürdüğü bu deniz alanında, Kanada kıta sahanlığını genişletme adına bilimsel bilgiye ulaşamamış ve ABD'nin BMDHS'ye taraf olmaması sebebiyle de işbirliğinden başka çözüm yolu olmadığ1 ortaya çıkmtıştır (Castonguay, 2017: 88). Barents Denizi'nde de Rusya ve Norveç arasında uyuşmazlık yaşanmaktadır ve bu bölgede ikili anlaşmalarla sorun çözüme kavuşturulmaya çalışılmaktadır. 2010 yılında imzalanan Barents Denizi ve Arktik Okyanusu'nda Deniz Sınırı Antlaşması Rusya ve Norveç arasındaki çatışmalı bölge için bir çözüm sunmuş ve iki ülke arasında Bölge'de karşlıklı işbirliği faaliyetleri görülmeye başlamıştır (Jensen, 2011: 151-168).

Deniz yetki alanları sorunları arasında gösterilen diğer uyuşmazlıklar ise Arktik Okyanusu'na kıyısı olan ülkelerin iddialarının ortaya koymuş olduğu kitasal sirt olarak anilan Lomonosov ve Alpha -Mendeleyev Sirtlarr'dır (İnan, Şimşek, 2016: 102-105). Lomonosov Sirtı'nda egemenlik iddiasında bulunan ülkeler Rusya, Kanada ve Danimarka'dır ve bu sırt üzerindeki egemenlik iddiaları kıta sahanlı̆ı̆ın genişletmeye yarayacağından dolayı önem arz etmektedir (Currie, 2007: 9). Ancak bu sirt üzerindeki iddialar, buzlu koşullarda bilimsel verilere ulaşılamaması nedeniyle sonuçsuz kalmış ve bu nedenle ulus devletlerin bu alan üzerindeki çatışma olasılıkları devam etmektedir (Weber, 2009: 661). Alpha-Mendeleyev Sırtı üzerindeki uyuşmazlıkta Rusya, Kanada ve Danimarka'nın yanında ABD'de söz sahibi olmaya çalışmaktadır. Bu sırt buzlu koşullar nedeniyle çok fazla keşfedilemediğinden dolayı potansiyel çatışma olasılıklarını içinde barındırmakta ve kıyıdaş ülkeler egemenlik iddialarını saklı tutmaktadırlar (Weber, 2009: 664).

Bering Boğazı'nın yanında Kuzeybatı Geçidi ve Kuzeydoğu Geçidi üzerinde uyuşmazlık söz konusudur. Bu geçitlerdeki uyuşmazlıklar, uluslararası geçit mi yoksa milli yetki sınırları içerisinde olan geçit mi sorunsalı üzerinedir (Currie, 2007: 5). Kuzeybatı geçidi üzerinde egemenlik iddiasında bulunan Kanada, 2015 yllında çevre koruma adına tek taraflı yapmış olduğu bir düzenleme ile buradaki kıta sahanlı̆̆ını 200 mile çlkarmıştır (Arctic Waters Pollution Prevention Act, 2015). Kuzeybatı Geçidi üzerindeki bu yasal düzenlemeye karşılık Kuzeydoğu Geçidi'nde Rusya'nın egemenlik iddiaları ve Bölge'deki faaliyetleri devam etmektedir. ABD'nin bu geçidin uluslararası geçit olduğu yönündeki 1srarlarına karşın Rusya bu geçidi iç sularına dâhil etmektedir (Bryanski, 2011).

Arktik Okyanusu'nda bulunan kara parçaları üzerinde de uyuşmazlık söz konusudur. Uyuşmazlığın yüksek olduğu kara parçalarına Hans Adası ve Svalbard takımadaları örnek gösterilebilir. Hans Adası, uluslararası geçit yolları üzerinde yer almakta ve 1970 'lerden bu yana Kanada ve Danimarka arasında anlaşmazlı̆̆a sebep olmaktadır (European Parliament Briefing, 
2017: 3). Diplomatik yollarla çözüm bulunmaya çalışılan Hans Adası'nın statüsü halen daha çözüme kavuşamamıştır. Hans Adası'na nazaran Svalbard Takımadaları'nın statüsü 1920 yılında imzalanan çok taraflı bir antlaşma ile sağlanmaktadır (Spitsbergen Treaty, 1920). Bu adadaki anlaşmazlık ise garantör ülke olan Norveç’in adanın kıta sahanlığını kendi egemenlik alanı olarak ilan etmesi ve Rusya'nın bu konudaki endişeleri üzerine gelişmektedir (Kriz ve Chrastansky, 2012: 121).

Deniz yetki alanlarındaki uyuşmazlıklara ikili işbirliği girişimleri ile çözüm bulmaya çalışan ulus devletler, tüm insanlığı ilgilendiren meselelere çok taraflı işbirlikleri ile karşılık vermişlerdir. Arktik Konseyi'nin kurulmasının yanında Arktik Okyanusu için en önemli belgelerden biri 2008 tarihli Ilulissat Deklarasyonu'dur. Bu doküman, uluslararas1 toplumun Arktik Okyanusu'ndaki faaliyetlerinde k1sıtlayıcı bir etkiye sahiptir. Arktik 5'lisi tarafindan oluşturulan bu belge, uluslararası deniz hukukunun oluşturduğu yapıyı Bölge için en kapsayıcı düzenleme aracı olarak görmekte ve başka bir düzenlemeye ihtiyaç duyulmadığını ortaya koymaktadır. Ayrıca deniz ve çevresinin korunması hususunda da Uluslararası Denizcilik Örgütü (International Maritime Organization-IMO) ile çalışılacă̆ını belirtip, sadece Bölge'yi ilgilendiren bir yapının oluşmayacağının altını çizmektedir (Ilulissat Declaration, 2008).

Uluslararası Denizcilik Örgütü'nün faaliyetleri, uluslararası toplumun Bölge'deki varlığını ortaya koymaktadır. IMO, BM bünyesinde oluşturulan ve uluslararası gemicilik emniyeti ve güvenliği ile denizlerin ve atmosferin gemilerden kaynaklanan sebeplerle kirlenmesinin önlenmesini düzenleyen bir kurumdur (International Maritime Organization Web Sitesi). Oluşturmuş olduğu konvansiyonlarla Arktik Okyanusu üzerindeki faaliyetleri denetleyen çok aktörlü bir yap1 olan IMO, Gemi Kirliliğini Önleme Uluslararası Sözleşmesi (MARPOL), Denizde Can Emniyeti Uluslararası Sözleşmesi (SOLAS) ve Kutup Sularında Faaliyet Gösteren Gemiler için Uluslararası Kod (Polar Code) ile kıyı ülkelerini bağlayıcı kararlar almaktadır (Ocean Conservancy, 2017: 33-34). Bütün bu işbirliği girişimleri çok aktörlü bir yap1 arz etmektedir ve bağlayıcılığı olan bir mekanizma sunmaktadır.

Ilulissat Deklarasyonu içerisinde belirtildiği gibi uluslararası deniz hukuku, Bölge için çözüm olanakları sunmaktadır. Bu amaçla 1982 tarihli Birlemiş Milletler Deniz Hukuku Sözleşmesi’ne biraz değinmek yerinde olacaktır. BMDHS, deniz alanları üzerinde kapsayıcı birtakım kurallar içermekte ve yaratmış olduğu kurumlarla ulus devletlerin sorunlarına çözüm bulmaya çalışmaktadır. Devlet üzerinde bir düzen oluşturmayı amaçlayan bir uluslararası kurumsallaşma örneği olan BMDHS'ye bağlı Uluslararası Deniz Yatağ1 Otoritesi, Kıta Sahanlığı Sinırlama Komisyonu ve Uluslararası Deniz Hukuku Mahkemesi adli kurumlar bulunmakta ve bu kurumlar ulus devletlerin deniz yetki alanlarında ve deniz yetki alanları ötesinde kalan 
uyuşmazlıklarına birtakım kurallar getirmektedir (Oceans \& Law of The Sea). İngiliz Okulu'nun ortaya atmış olduğu birincil kurumlardan birisi olan uluslararası hukuk, Arktik örneğinde görüldüğü gibi aktörler arası işbirliği olan bir uluslararası toplum yaratmıştır. Uluslararası hukukun ortaya koymuş olduğu düzenlemeleri dikkate alan kıyıdaş ülkeler, işbirliğinin avantajlı sonuçlarını dikkate alarak ulusal çıkarları gereği hareket etmişlerdir. Hans Adası, Lomonosov Sırtı gibi alanlarda halen daha görülen uyuşmazlıklar ise işbirliğinin görece daha kârlı olduğu anlaşıldığında çözüme kavuşacaktır. BMDHS'nin bağlayıcı yapısı bir nevi güçler dengesi oluşturmakta, sistemin dışında kalan $\mathrm{ABD}$ bile ortaya konan düzenin kurallarına göre hareket etmektedir.

Uluslararası düzen uluslararası hukuk anlamına gelmemekte, uluslararas1 politikanın araçlarıyla oluşturulabilmektedir (Bull, 2002: xxxiv). Uluslararası düzen oluşturmak devletler toplumunun ya da uluslararası toplumun öncelikli konuları arasında yer almaktadır. Uluslararası düzen, iki ya da daha çok devletin birbirlerinin kararlarını etkileyebilecekleri etkili bir birliktelik kurarak devletler toplumunu ya da uluslararasi toplumu kurması anlamina gelmektedir (Bull, 2002: 9). Arktik Bölgesi'nde İngiliz Okulu'nun kurularından olan diplomasinin ağır basması bölgedeki işbirliklerine etki etmiş ve uluslararası hukuk kurumlarından da yararlanılarak bir düzen oluşturulmuştur. Bölgede'ki mevcut düzen çoğulcu anlayışın ön planda olduğunu ortaya koymaktadır.

\section{Sonuç}

Sürdürülebilirliği merkezine alan yönetişim sistemleri, bugünün koşullar1 ile gelecek nesillerin ihtiyaçlarını göz önünde bulundurarak; çevre koruma, ekonomik faaliyetler ve sosyal refahı dengelemeye çalışmaktadır (Berkman et al., 2016: 187). Bu tip yönetişim sistemleri ideal olanı ortaya koymakta ve kendisine eklemlenen ulus devletlere de birtakım ayrıcalıklar kazandırmaktadır. Kutup Bölgeleri'ndeki hukuki, politik ve ekonomik yap1 incelendiğinde de iki Kutbu'n yönetimsel olarak birbirinden tamamen farklı olduğu görülmekte ve bu durum, ideal olan hakkında karmaşaya sebep olmaktadir.

Arktik'in ve Antarktika'nın statüsünün uluslararası ilişkiler teorilerinden İngiliz Okulu ile değerlendirildiği bu çalışma, uluslararası toplumun bu bölgelerdeki faaliyetlerine odaklanmıştır. İki kutbun tarihsel bir perspektifle Kutuplar'da geçirmiş olduğu dönüşüm ele alınmış, özellikle Arktik'e nazaran Antarktika'da uluslararası toplumun çoğulcudan dayanışmacıya dönüşümüne tanıklık edilmiştir. 20. yüzylın başlarına kadar götürülebilecek olan Antarktika üzerindeki devletler toplumunun faaliyetleri, özellikle 20. yüzyllin ikinci yarısında dönüşüme uğramış ve Kıta üzerinde çok aktörlü bir yap1 karşımıza çıkmıştır. Yaşanan bu dönüşüm, Antarktika Antlaşması'na taraf olmayan ülkelere yeterli gelmemiş ve 1991 Madrid Protokolü ile Antarktika 
insanlığın ortak mirası statüsünü tamamen kazanmıştır. 2048 yllına kadar sürecek olan Antarktika üzerindeki bu sistemin devamı halinde, Kita üzerinde tüm insanlık adına hareket edilecek ve ortaya konan küresel adalet, düzenin devamını sağlayacaktır. Uluslararası toplumun çevre koruma faaliyetleri adı altında Antarktika'da dayanışmacı bir tutum sergilemeleri, İngiliz Okulu'nun ortaya koyduğu önemli kurumlarla açıklanabilmektedir. Güç mücadelesi, uluslararası hukuk ve diplomasi kurumlarının ATS'nin gelişiminde etkili olduğu görülmekte ve adalet-düzen tartş̧masında, adaletin sağlanarak düzenin oluşturulduğu ortaya konulmaktadır. Dünya üzerindeki tek barışçıl kıta olan Antarktika üzerinde uluslararası toplumun varmış olduğu konsensüsün Arktik için örnek teşkil edip etmeyeceği merak uyandırmaktadır.

Arktik Bölgesi içerisinde yaşanan sorunlar dikkate alındığında İngiliz Okulu'nun çoğulcu anlayışının bölgede hâkim olduğu görülmektedir. Devlet temelli çoğulcu İngiliz Okulu teorisinin, çevresel faktörleri devlet için dikkate alan bir anlayışın bölge ülkeleri üzerinde etkili olmasının birtakım örnekleri bulunmaktadır. Kanada'nın Kuzeybatı Geçidi'ni çevre koruma adına milli yetki sınırları içerisinde göstermesinin ona kazandırdığı ekonomik kazanç, bu davranışının küresel adalet anlayışı çerçevesinde sorgulanmasına sebebiyet vermektedir. Arktik Bölge'de düzen-adalet ayrımında düzen faktörünü ön plana çıkarak, bölgesel işbirliklerinin de bu düzeni oturtmaya yönelik olduğu aşikârdır. Çevre koruma adına atılmış adımlar, kıyıdaş ülkelerin kendi egemenlik sahalarının güvenliğinin sağlanması ve ülkesellik kurumunun ön plana çıkmasına yol açmaktadır.

Uluslararası toplumun iki ayrı Kutup politikalarında göstermiş olduğu hukuki, politik ve ekonomik farkllıkların temelinin ne olduğu sorusu üzerine düşünülecek olursa, güç mücadelesi, uluslararası hukuk ve diplomasi kurumlarının sorgulanması gerektiği sorunsalının ortaya çıkmaktadır. Güney Kutbu ve Kuzey Kutbu politikalarında İngiliz Okulu'nun iki ayrı anlayışının hâkim olduğunun görülmesi; hem bölgenin coğrafik karakteristiğinin hem de o Bölge etrafindaki büyük güçler faktörünün farklıllğından gelmektedir. Arktik Bölgesi'nden çok daha önce Antarktika'da başlayan güç mücadelesi, uluslararası toplumun Antarktika'da daha önce genişlemesini sağlamıştır. Antarktika'da çoğulcu anlayıştan dayanışmacı anlayışa evrilen politik ve hukuki sürecin aksine Arktik'te devlet merkezli çoğulcu anlayış egemendir. Dayanışmacı perspektifin Kuzey Kutup Bölgesi üzerindeki çatışmaların geleceğine 1ş1k tutup tutamayacağı ise ayrı bir tartışma konusudur. 


\section{Kaynakça}

Ağkaya, O. (2016). "İngiliz Okulu ve Uluslararası Toplum Düşüncesi”. Ankara Üniversitesi SBF Dergisi, 71(4): 1059-1089.

Anderson, R. T. (2008). "The Antarctic Scene: Legal and Political Facts". G. D. Triggs. (Ed.). The Antartic Treaty Regime: Law, Environment and Resources. Cambridge University Press, United Kingdom. 67-64.

Antarctic Treaty Secretariat. (2011). "The Antarctic Treaty". http://www.ats.aq/e/ats.htm (erişim tarihi: 26 Temmuz 2017).

Antarctic Treaty Parties. https://www.ats.aq/devAS/ats_parties.aspx?lang=e (erişim tarihi: 30 Temmuz 2019).

Arctic Council Member States. (2015). https://arcticcouncil.org/index.php/en/about-us/member-states (erişim tarihi: 26 Temmuz 2019).

Arctic Council Working Groups. (2015). https://arcticcouncil.org/index.php/en/about-us/working-groups (erişim tarihi: 3 Ağustos 2019).

Arctic Environmental Protection Strategy. (1991). http://library.arcticportal.org/1542/1/artic_environment.pdf (erişim tarihi: 3 Ağustos 2019).

Arctic Waters Pollution Prevention Act. (2015). https://lawslois.justice.gc.ca/eng/acts/a-12/ (erişim tarihi: 5 Ağustos 2019).

Attenborough, D. (2011). Frozen Planet Belgeseli-To the Ends of the Earth, BBC ve The Open University.

Atvur, S. (2017). "Ekolojik Perspektifte Antarktika'da Güvenlik". H. Gümrükçü, G. Ersoy, et al. (Ed.). Küresel Bakıısla Kutup Çăğ-3: Taribi ve Hukuki Perspektif-Ekolojik Dönüsïm. Efil Yayınevi. Ankara, 89109.

Başlar, K. (1998). The Concept of the Common Heritage of Mankind in International Law. Martinus Nijhoff Publishers. United Kingdom.

Berkman, P. A. (2011). "President Eisenhower, The Antarctic Treaty, and the Origin of International Spaces". P. A. Berkman, M. A. Lang, D. W. H. Walton ve O. R. Young (Ed.). Science Diplomacy: Antartica, Science, and the Governance of International Spaces. Smithsonian Institution Scholarly Press, Amerika Birleşik Devletleri. 17-27. 
Berkman, P. A., Vylegzhanin, A. N. ve Young, O. (2016). "Governing the Bering Strait Region: Current Status, Emerging Issues and Future Options". Ocean Develompent and International Law, 47 (2): 186-217.

Birleşmiş Milletler Deniz Hukuku Sözleşmesi - BMDHS. (1982). https://www.un.org/depts/los/convention_agreements/texts/un clos/unclos_e.pdf (erişim tarihi: 26 Temmuz 2019).

Boyd, R., Bjerkgard, T., Nordahl, B. ve Schiellerup, H. (2016). Mineral Resources in Arctic: An Introduction. Geological Survey of Norway. Norway.

Bryanski, G. "Russia's Putin says Arctic Trade Route to Rival Suez". Reuters, 22.09.2011.

Bull H. (1984a). "The Emergence of a Universal International Society". H. Bull ve A. Watson (Ed.). The Expansion of International Society. Clarendon Press, United States of America. 117-126.

Bull, H. (1984b). "The Revolt Against West" H. Bull ve A. Watson (Ed.). The Expansion of International Society. Clarendon Press, United States of America. 217-228.

Bull, H. (2002), The Anarchical Society: A Study of Order in World Politics. Palgrave, United States of America, 3. Bask1.

Bull, H. ve Watson, A. (1984). The Expansion of International Society. Clarendon Press, United States of America.

Buzan, B. (1993). "From International System to International Society: Structural Realim and Regime Theory Meet the English School". International Organization. 47 (3): 327-352.

Buzan, B. (2001). "The English School: An Underexploited Resource in IR". Review of International Studies. 27 (3): 471-488.

Buzan, B. (2015). Uluslararası İlişkilerde İngiliz Okulu. (Çev. H. Özdemir), Uluslararası İlişkiler Kütüphanesi-Röle Akademik Yayıncılık, İstanbul.

Byers, M. (2013). International Law and the Arctic. Cambridge University Press, United Kingdom.

CIA-Central Intelligence Agency. (2017). "The World Factbook: Antarctica". https://www.cia.gov/library/publications/the-worldfactbook/geos/ay.html (erişim tarihi: 08.06.2017).

Coburn, S. (2017). "Eyeing 2048: Antarctic Treaty System's Mining Ban", Columbia Journal of Environmental Law, 42(2): 1-6. 


\section{Aybüke INAAN ŞİMŞEK}

Commission for the Conservation of Antarctic Marine Living Resources (CCAMLR). https://www.ccamlr.org/en/organisation/aboutccamlr (erişim tarihi: 15.07 .2015$)$.

Convention on the Regulation of Antarctic Mineral Resources Activities (CRAMRA), https://www.ats.aq/documents/recatt/Att311_e.pdf, (erişim tarihi: 08.09.2015).

Costonguay, N. (2017). "The Efficiency of Institutions in Regards to Disputes within the Arctic: A Case Study of the Beaufort Sea and the Barents Sea Disputes". Ecole Nationale d'Administration Publique.

Currie, D. E. J. (2007). "Sovereignty and Conflict in the Arctic Due to Climate Change: Climate Change and Legal Status of the Arctic Ocean" LL.B. (Hons.) LL.M., Legal Adviser Greenpeace International.

Cutler, A. C. (1991). "The "Grotian Tradition in International Relations". Review of International Studies, 17: 41-65.

Devlen, B. ve Özdamar. (2010). "Uluslararası İlişkilerde İngiliz Okulu Kuramı: Kökenleri, Kavramları ve Tartısmaları". Uluslararası İliskiler Dergisi, 7(25): 43-68.

Drewry, D. J. (2008). “The Antarctic Physical Environment”. G. D. Triggs (Ed.). The Antarctic Treaty Regime: Law, Environment and Resources. Cambridge University Press, United Kingdom, 6-27.

Dunne, T. (1998). Inventing International Society: A History of the English School. MacMillan Press, Great Britain.

European Parliament Briefing. (2017). "Arctic Continental Shelf Claims Mapping Interests in the Circumpolar North". https://cor.europa.eu/en/engage/studies/Documents/EPRS_BR I(2017)595870_EN.pdf (erişim tarihi: 5 Ağustos 2019).

Hatipoğlu, E. (2014). "Uluslararası İlişkilerde İngiliz Okulu". T. Arı (Ed.), Postmodern Uluslararası İliskiler Teorileri 2: Uluslararası Illiskilerde Eleştirel Yaklaşımlar. Dora Basım Yayın Dağıtım, Bursa, 125-148.

Hayashi, M. (1986). "The Antarctica Question in the United Nations". Cornell International Law Journal. 19(2): 275-290.

Heywood, A. (2013). Siyaset. Özipek, B. B., Şahin, B., Yıldız, et al. (çev.). Adres Yayınları, Ankara. 9. Bask1.

Ilulissat Declaration. (2008). https://cil.nus.edu.sg/wpcontent/uploads/2017/07/2008-Ilulissat-Declaration.pdf (erişim tarihi: 5 Ağustos 2019). 
Uluslararası Toplumun Kutup Politikaları: Atktik-Antarktika Karşıl...

International Maritime Organization. http://www.imo.org/en/About/Pages/Default.aspx (erişim tarihi: 5 Ağustos 2019).

İnan Şimşek, A. (2016). “Arktika Bölgesi’ndeki Deniz Yetki Alanlarındaki Çatışmalara Genel Bakış”. H. Gümrükçü, A. İnan Şimşek ve G. Ersoy (Ed.). Küresel Bakışla Kutup Çăgl: Farkh Disiplinler, Cok Yönlü Perspektifler. Efil Yayınevi. Ankara, 93-118.

İnan Şimşek, A. (2018). "Küresel İklim Değişikliğinin Bir Sonucu Olarak Kutuplarda Yönetişim Tartışmaları". İktisat ve Toplum Dergisi, 91: 49-55.

Jensen, O. (2011). "The Barents Sea: Treaty between Norway and the Russian Federation concerning Maritime Delimitation and Cooperation in the Barents Sea and the Arctic Ocean". International Journal of Marine and Coastal Law, 26(1): 151-168.

Joint Statement of the President of the United States of America and the President of the Russian Federation on Cooperation in the Bering Strait Region. (2011). https://obamawhitehouse.archives.gov/thepress-office/2011/05/26/joint-statement-president-united-statesamerica-and-president-russian-fe (erişim tarihi: 3 Ağustos 2019).

Jones, R. E. (1981). "The English School of International Relations: A Case for Closure”. Review of International Studies, 7: 1-13.

Kiss, A. (1985). "The Common Heritage of Mankind: Utopia or Reality?" International Journal. 40(3.): 423-441.

Kolak, J. J. (2011). “Geological Context”. Bartels, L. H. ve Brenda, P. (Eds.). An Evaluation of the Science Needs to Inform Decisions on Outer Continental Shelf Energy Development in the Chukchi and Beaufort Seas, Alaska. US. Geological Survey Circular 1370, Amerika Birleşik Devletleri. 13-40.

Kriz, Z. ve Chrastansky, F. (2012). "Existing Conflicts in the Arctic and the Risk of Escalation: Rhetoric and Reality". Perspectives-The Review of International Affairs. 20(1): 111-139.

Kuersten, A. (2016). "The Arctic Five versus the Arctic Council". L. Heininen, H. Exner-Pirot ve J. Plouffe (Ed.). Arctic Yearbook 2016. Northern Research Forum, İzlanda. 389-395.

Linklater, A. (2010). "The English School Conception of International Society: Reflections on Western and non-Western Perspectives". Ritsumeikan Annual Review of International Studies, 9: 1-13. ISSN: 1347-8214. 


\section{Aybüke INAAN ŞİMŞEK}

Linklater, A. (2013). "İngiliz Okulu". S. Burchill, A. Linklater, et al. (Ed.), Uluslararası İlişkiler Teorileri. M. Ağcan ve A. Aslan (Çev.), Küre Yayınları, İstanbul.

Maquieira, C. (1986). "Antarctica Prior to the Antarctic Treaty: A Political and Legal Perspective". Antarctic Treaty System: An Assessment. National Academy Press, Amerika Birleşik Devletleri. 49-54.

National Academy of Sciences. "The International Geophysical Year." http://www.nas.edu/history/igy/ (erişim tarihi: 18 Temmuz 2017).

Ocean Conservancy. (2012). Navigating the North: An Assessment of the Environmental Riskes of Arctic Vessel Traffic. Amerika Birleşik Devletleri.

Oceans \& Law of The Sea - United Nations. https://www.un.org/depts/los/convention_agreements/conventi on_overview_convention.htm (erişim tarihi: 6Ağustos 2019).

Owens, J. (2011). "The Legal Status of the Bering Strait". China Oceans Law Review, 13(1): 85-113.

Palabıyık, M. S. (2015). "İngiliz Okulu”. R. Gözen (Ed.), Uluslararası Ilişkiler Teorileri. İletişim Yayınları, İstanbul, 217-255.

Ronnfeldt C. F. (1999). "Beyond a Pluralist Conception of International Society?: A Case Study on the Intarnational Response to the Conflict in Bosnia - Hercegoniva". Cooperation and Conflict, 34(2): 141-168.

Ross, E. (2003). “Origins of the Antarctic Treaty: 1908-1959". University of Canterbury Review, 502: 2-11.

Sanır, F. (2000). Coğrafya Terimleri Söəlï̈̆ü, Gazi Kitabevi, Ankara.

Scientific Committee on Antarctic Researh. https://www.scar.org/ (erişim tarihi: 6 Ağustos 2019).

Spitsbergen Treaty. (1920). https://www.loc.gov/law/help/ustreaties/bevans/m-ust000002-0269.pdf (erişim tarihi: 5 Ağustos 2019).

Tepper, R. ve Haward, M. (2005). “The Development of Malaysia's Position on Antarctica: 1982 to 2004”. Polar Record, 41 (2): 113-124

The Antarctic Treaty. (1959). https://www.ats.aq/e/ats.htm (erişim tarihi: 23 Temmuz 2019). 
The Arctic Council: A Backgrounder. (2018). https://arcticcouncil.org/index.php/en/about-us (erişim tarihi: 3 Ağustos 2019).

"Points in the Bering Sea Case", The Chicago Sunday Tribune, 26.03.1893.

The Protocol on Environmental Protection to the Antarctic Treaty. (1991). https://www.ats.aq/e/ep.htm (erişim tarihi: 24 Temmuz 2019).

Triggs, G. D. (2008). The Antarctic Treaty Regime: Law, Environment and Resources. Cambridge University Press, United Kingdom.

USGS - U.S. Geological Survey. (2008). "Circum Arctic Resource Apprasial: Estimates of Undiscovered Oil and Gas North of the Arctic Circle". https://pubs.usgs.gov/fs/2008/3049/fs2008-3049.pdf (erişim tarihi: 26 Temmuz 2019).

Uysal Oğuz, C. (2017). "Inuit Halkı ve İklim Değişikliği”. H. Gümrükçü, G. Ersoy, A. İnan Şimşek ve F. C. Yaşar Dinçer (Ed.). Küresel Bakışla Kutup Çăğ 3: Taribi ve Hukuki Perspektif -Ekolojik Dönüșïm. Efil Yayınevi, Ankara. 111- 131.

Uysal Oğuz, C. ve Ersoy, G. (2016). "Kutuplardaki İklim Değişikliğinin Bölgesel ve Küresel Etkileri”. H. Gümrükçü, A. İnan Şimşek ve G. Ersoy (Ed.). Küresel Bakeşla Kutup Çăgr: Farkh Disiplinler, Çok Yönlï Perspektifler. Efil Yayınevi. Ankara, 157-170.

Vicuna, F. O. (2008). "The Antarctic Treaty System: A Viable Alternative fort he Regulation of resource-orianted activities". G. D. Triggs, (Ed.). The Antarctic Treaty Regime: Law, Environment and Resources. Cambridge University Press, United Kingdom. 65-76.

Vigni, P. (2000). "The Interaction Between the Antarctic Treaty System and the Other Relevant Conventions Applicable to the Antartctic Area", J. A. Forewein ve R. Wolfrum (Ed.), Max Planck Yearbook of United Nations Law, Kluwer Law International, Hollanda, 481-542.

Viotti, P. R. ve Kauppi M. V. (2012). International Relations Theory. Pearson Education, United States of America. 5. Basim.

Vitebski, P. (2005), "The Arctic is a Homeland", http://www.thearctic.is/PDF/homeland.pdf (erişim tarihi: 21 Mart 2015).

Watson, A. (1987). "Hedley Bull, States Systems and International Societies". Review of International Studies, 13(2): 147-153.

Weber, M. (2009). "Defining the Outer Limits of the Continental Shelf Across the Arctic Basin: The Russian Submission, States' Rights, 


\section{Aybüke İNAN ŞİMŞEK}

Boundary Deliminat.on and Arctic Regional Cooperation". The International Journal of Marine and Coastal Law, 24(4): 653-681.

Wight, M. (1992). The International Theory: Three Traditions, Holmes \& Meier Publishers, United States of America.

Young, O. (2004). "The Structure of Arctic Cooperation: Solving Problems/Seizing Opprtunities". The Fourth Conference of Parliamentarians of Arctic Region, Finlandiya.

Young, O. (2017). "Why Should We Take an Interest in What Happens in Antarctica?". K. Dodds, A. D. Hemmings ve P. Roberts (Ed.). Handbook on the Politics of Antarctica. Edwar Elgar Publishing, United Kingdom. xiv-xvi. 